\title{
COMPARING THE APPLE IPAD AND NON-APPLE CAMP TABLET PCS: A MULTICRITERIA DECISION ANALYSIS
}

\author{
Pei-Hsuan TSAI, Shun-Chiao CHANG \\ Department of Business Administration, National Taiwan University of Science and Technology, \\ No. 43, Sec. 4, Keelung Road, 10607 Taipei, Taiwan
}

Received 06 November 2012; accepted 27 Apr 2013

\begin{abstract}
This study mainly evaluates the performances of Tablet PCs such as the Apple iPad based on a benefits, opportunity, costs, and risks (BOCR) conceptual framework with qualitative and quantitative criteria. We apply four methods, namely, the multiple-criteria decision-making (MCDM) tools (grey relational analysis (GRA), the technique for order performance by similarity to ideal solution (TOPSIS), the VlseKriterijumska Optimizacija I Kompromisno (VIKOR) method, and fuzzy approach) to evaluate and select the tablet PCs' rankings and then construct a tablet PCs evaluation performance model under an analytic hierarchy process (AHP). The empirical results reveal that a firm's revenue growth, capacity for profitability, product design and product function are highly important evaluation indexes. This indicates that Tablet PC companies should channel more efforts into their product innovation for creating revenue growth and maintaining customer loyalty. Finally, fuzzy AHP also leads to the same findings.
\end{abstract}

Keywords: tablet PCs, multiple-criteria decision-making, analytic hierarchy process (AHP), product innovation, fuzzy AHP.

Reference to this paper should be made as follows: Tsai, P.-H.; Chang, S.-C. 2013. Comparing the Apple iPad and non-Apple camp tablet PCs: a multicriteria decision analysis, Technological and Economic Development of Economy 19(Supplement 1): S256-S284.

JEL Classification: C44, C51, C52.

Corresponding authors Pei-Hsuan Tsai, Shun-Chiao Chang

E-mail:pei.hsuan0616@gmail.com; scchang@ba.ntust.edu.tw 


\section{Introduction}

The CEO of Apple, Steve Jobs, first launched the tablet PC “iPad" on January 27, 2010, and generated sales of about 14 million of the tablets in the same year. He not only introduced an innovative product, but also opened up a new market of pan PC/NB-related products. Apple iPad adopted an acceleration sensor, a capacitive multi-touch, iPhone operating system coupled with a QWERTY software keyboard. iPad provides support for games and software applications downloaded from the Apple store and it also provides e-books for on-line store iBooks that can read colour-display e-books, newspapers and magazines.

The killer application of the iPad is the App Store plus iTunes. In the stores, various programs are available for users to download which attracts many users outside the PC users. The platform represents the successful experiences accumulated by Apple from the iPod to the iPhone in which software can make more money than hardware. Obviously, two key barriers preventing other competitors from entering the tablet PC market are operating systems and application platforms. Most of them have to rely on Microsoft Windows RT or Google Android, HP WebOS and RIM QNX for their operating systems. However, if they only focus on the development of hardware, they may face the same situation as those selling e-book readers in that the sales performance is not as good as expected due to the sparse content (application programs). Therefore, Google, the leader of the non-Apple camp, has had to engage in the Android operating system and Android Market application programs to help its partners to adopt integration across hardware and software.

Undoubtedly, the upsurge of tablet PCs has swept all over the world and brought tsunamilike demand in recent years. According to data compiled by Garther (2012), the global output of tablet PCs jumped to 60 million in 2011. As for the prospects for the future, with more and more operators entering the battlefield of tablet computers, the output is predicted to reach 208.3 million in 2014. Due to the popularity of the iPad, global key PC/NB and consumer electronics manufacturers are channelling resources to produce tablet PCs in the hope that they can have a share of the market. The leading NB firms such as HP, Dell, Acer, Lenovo and Asus, as well as smart phone leaders such as Samsung, Nokia, RIM, HTC and Motorola have introduced iPad-like products to compete for a share of the tablet PC market ${ }^{1}$.

There is so far no complete set of evaluation models of the tablet PC market for the reference of the tablet PC firms in their operations even though the tablet PC has rapidly been popularized. In this study, we consider a couple of criteria to assess the tablet PC, namely, quantitative indicators (i.e. prices, revenue growth and profitability) and qualitative indicators (i.e. brand attractiveness). As a decision method, the analytic hierarchy process (AHP) or fuzzy AHP decomposes a complex multi-criteria decision-making (MCDM) problem into a hierarchy (Secme et al. 2009; Büyüközkan et al. 2011; Wu et al. 2009b, 2010, 2011a; Bentes et al. 2012; Choudhary, Shankar 2012; Cox 2012). Therefore, this study addresses the concept

Because there is no specific name for the tablet PC products similar to the Apple iPad, we refer to them as "iPadlike" products that include the Samsung Galaxy Tab, Motorola Xoom, HP TouchPad, BlackBerry PlayBook, Asus Eee Pad Transformer and Acer Iconia Tab W500. From the viewpoint of their characteristics, the iPad and iPad-like products should be closer to consumer electronics products related to the PC or NB. 
of benefits, opportunity, costs, and risks (BOCR) ${ }^{2}$ to construct an alternative to the performance measurement for tablet PCs as well as selection models for tablet-PC firms under AHP and fuzzy AHP hierarchical forms, respectively (Saaty, Ozdemir 2003; Wijnmalen 2007).

In the literature, there are few MCDM theories aimed at evaluating the performances of consumer electronics products multi-dimensionally (Tsai 2012). This study provides the following four MCDM methods, namely, AHP-grey relational analysis (AHP-GRA), the AHP-technique for order performance by similarity to ideal solution (AHP-TOPSIS), AHP-VlseKriterijumska Optimizacija I Kompromisno (AHP-VIKOR) and Fuzzy AHP for constructing the Tablet PC's performance evaluation model. Based on the four perspectives of the BOCR research framework, AHP is first used to obtain the weights of the indexes. Then, the three MCDM analytical tools, GRA, TOPSIS, and VIKOR, are respectively used to evaluate and select the tablet $\mathrm{PC}$ rankings based on the weight of each index. On the other hand, we also utilize fuzzy AHP to evaluate the ranking of tablet PCs.

The empirical results reveal that the Apple iPad has the highest value and that the Samsung Galaxy Tab follows among the seven main tablet PCs in all four MCDM models. The results are consistent with the current realities in the tablet PC market in which the Apple iPad is the dominant tablet PC with a $54.7 \%$ market share and Samsung has a share of over 5\% in 2011 Q4 (International Data Corporation (IDC) 2012). Furthermore, the results of the AHP and FAHP analysis reveal that the benefits and opportunities are the two most important criteria for tablet PCs companies to improve the performance of their tablet PC products. As for revenue growth, the capacity for profitability, product design, and product function are highly important evaluation indexes, which indicates that Tablet PC companies should expend more efforts on their product innovation for creating revenue growth and maintaining customer loyalty. In other words, they should provide more product functions and fun features on their tablet PC products.

The reminder of this study is organized as follows. Section 1 provides an evaluation analysis (including the concept of the BOCR Model, and MCDM methods). Section 2 presents the study's empirical results and related discussions. Finally, the conclusions and managerial implications are then given in the last section.

\section{Evaluation analysis}

\subsection{The BOCR model}

The concept of BOCR (benefits, opportunity, costs, and risks) was developed by Saaty (1996), Saaty and Ozdemir (2003). The BOCR model has been widely applied to various fields, such as the high-tech industry (Eroğmuş et al. 2005; Lee et al. 2009), strategic selection (Chen et al. 2010a; Fouladgar et al. 2012), and project evaluation (Jung, Seo 2010).

In evaluating each solution, these four evaluation criteria may be sub-divided into more detailed sub-criteria that will help policy-makers to derive more perfect results from the

The concept of BOCR was developed by Saaty and Ozdemir (2003). In evaluating each solution, these four evaluation criteria could often cover every aspect that needs to be considered. If necessary, the four criteria may be sub-divided into more detailed sub-criteria that will help policy-makers to work out more perfect results of evaluation. 
evaluation. The four principles of evaluation are qualitative principles in this study. Therefore, we have adopted pairwise comparisons with AHP to obtain the weights of individual principles. Besides, in order to ensure the rationality of filling in questionnaires, we have performed consistency tests before calculating the values of weights and compiling the degree of the effects of each principle of evaluation for each solution. Subsequently, we have used the "proposal combination" method to consider the degree of the effects of maximum benefits brought to affect and control "benefits, opportunity, cost and risks" and the synthetic effects that it may cause in implementing two or more plans. In practice, the model should include not only all positive aspects of the evaluation, but it should also consider two aspects: the risks that in fact possibly occur and the costs that such risks possibly entail. However, like AHP, such a model also uses pairwise comparisons to confirm its relative weight. Any principle in BOCR has significant effects on the strategy choice and the chosen strategy has the highest weight. It explains why BOCR can find the best solution in combining the value of each strategy and can help us analyse the decision-making issues (Saaty, Ozdemir 2003; Wijnmalen 2007; Heo et al. 2012).

\subsection{Multiple criteria decision making}

This section introduces four multiple criteria decision making (MCDM) techniques, namely, fuzzy AHP (FAHP), GRA, TOPSIS and VIKOR. The three MCDM analytical tools of GRA, TOPSIS, and VIKOR are for ranking and improving the tablet PCs' performance (Secme et al. 2009; Wu et al. 2009a, 2010; Zavadskas, Turskis 2011; Baležentis et al. 2012; Chen 2012), while we use AHP to determine the relative weights of the main and sub-criteria. Another method, the FAHP, is structured to evaluate the proposed Tablet PC framework (Büyüközkan et al. 2011; Baležentis et al. 2012; Lee et al. 2011a). The details of the four methods are explained as follows.

\section{A. Grey relational analysis (GRA)}

GRA is a quantitative tool used to explore the similarities and dissimilarities among factors in developing dynamic processes (Deng 1982) and has been widely applied to various fields including performance evaluation (Wu et al. 2010), stock investments (Zhang et al. 2011), and service quality (Kuo, Liang 2011). One of the features of GRA is that both qualitative and quantitative relationships can be identified among complex factors with insufficient information (relative to conventional statistical methods). Under such conditions, the results generated by conventional statistical techniques may not be acceptable without sufficient data to achieve the desired confidence levels. By contrast, grey system theory can be used to identify major correlations among factors of a system with a relatively small amount of data. The procedure for performing GRA is as follows:

Step 1: Calculate the Grey Relation Grade

Let $X_{0}$ be the referential series with $k$ entities (or criteria) of $X_{1}, X_{2}, \ldots, X_{\mathrm{i}}, \ldots, X_{N}$ (or $N$ measurement criteria). Then:

$$
X_{i}=\left\{x_{i}(1), x_{i}(2), \ldots, x_{i}(j), \ldots, x_{i}(k)\right\}, i=1, \ldots, N .
$$


The grey relational coefficient between the compared series $X_{i}$ and the referential series of $X_{0}$ at the $j$ th entity is defined as: $\gamma_{0 i}(j)=\frac{\Delta \min +\Delta \max }{\Delta_{0 i}(j)+\Delta \max }$, where $\Delta_{0 i}(j)$ is the absolute value of the difference between $X_{0}$ and $X_{i}$ at the $j$ th entity, that is $\Delta_{0 i}(j)=\left|x_{0}(j)-x_{i}(j)\right|$, and $\Delta \max =\max _{i} \max _{j} \Delta_{0 i}(j), \Delta \min =\min _{i} \min _{j} \Delta_{0 i}(j)$. The grey relational grade $(\mathrm{GRG})$ for a series of $X_{i}$ is given as: $\tilde{A}_{0 i}=\sum_{j=1}^{K} w_{j} \tilde{\mathrm{a}}_{0 i}(j)$, where $w_{j}$ is the weight of $j$ th entity. If it is not necessary to apply the weight, take $\omega_{j}=\frac{1}{K}$ as an average.

Step 2: Data Normalization (or Data Dimensionless)

Before calculating the grey relation coefficients, the data series can be treated, based on the following three kinds of situation and the linearity of data normalization, to avoid distorting the normalized data. These are:

a) Upper-bound effectiveness measuring (i.e. the larger the better):

$$
x_{i}^{*}(j)=\frac{x_{i}(j)-\min _{j} x_{i}(j)}{\max _{j} x_{i}(j)-\min _{j} x_{i}(j)} .
$$

b) Lower-bound effectiveness measuring (i.e. the smaller the better):

$$
x_{i}^{*}(j)=\frac{\max _{j} x_{i}(j)-x_{i}(j)}{\max _{j} x_{i}(j)-\min _{j} x_{i}(j)} .
$$

c) Moderate effectiveness measuring (i.e. nominal the best):

If $\min _{j} x_{i}(j) \leq x_{o b}(j) \leq \max _{j} x_{i}(j)$, then $x_{i}^{*}(j)=\frac{\left|x_{i}(j)-x_{o b}(j)\right|}{\max _{j} x_{i}(j)-\min _{j} x_{i}(j)}$.

If $\max _{j} x_{i}(j) \leq x_{o b}(j)$, then $x_{i}^{*}(j)=\frac{x_{i}(j)-\min _{j} x_{i}(j)}{x_{o b}(j)-\min _{j} x_{i}(j)}$

If $x_{o b}(j) \leq \min _{j} x_{i}(j)$, then $x_{i}^{*}(j)=\frac{\max _{j} x_{i}(j)-x_{i}(j)}{\max _{j} x_{i}(j)-x_{o b}(j)}$, where $x_{o b}(j)$ is the objective value of
entity $j$.

\section{B. The TOPSIS method}

The TOPSIS method (Hwang, Yoon 1981) simultaneously considers the distances between a positive ideal solution (PIS) and a negative ideal solution (NIS). 
In this study, the final ranking of tablet PCs using the TOPSIS method is based on 'the relative similarity to the ideal solution', which avoids similarities between ideal and negative ideal solutions. The TOPSIS steps are as follows:

a) Establish a decision (D) matrix for alternative performance:

$$
D=\begin{gathered}
A_{1} \\
A_{2} \\
\vdots \\
A_{i} \\
\vdots \\
A_{m}
\end{gathered}\left[\begin{array}{cccccc}
X_{11} & X_{12} & \cdots & \cdots & X_{1 j} & X_{1 n} \\
X_{21} & X_{22} & \cdots & \cdots & X_{2 j} & X_{2 n} \\
\vdots & \vdots & \cdots & \vdots & \vdots & \vdots \\
X_{i 1} & X_{i 2} & \vdots & \vdots & X_{i j} & X_{i n} \\
\vdots & \vdots & \cdots & \vdots & \vdots & \vdots \\
X_{m 1} & X_{m 2} & \cdots & \cdots & X_{m j} & X_{m n}
\end{array}\right],
$$

where: $A_{i}$ denotes the possible alternatives, $i=1, \ldots, m$; $X_{j}$ represents attributes or criteria relating to alternative performance, $j=1, \ldots, n$; and $X_{i j}$ is a crisp value denoting the performance rating of each alternative $A_{i}$ with respect to each criterion $X_{j}$.

b) Normalize the $D$ matrix.

Calculate the normalized decision matrix $\mathrm{R}\left(\mathrm{R}=r_{i j}\right)$. The normalized value $r_{i j}$ is calculated as follows:

$$
r_{i j}=\frac{X_{i j}}{\sqrt{\sum_{j=1}^{n} X_{i j}^{2}}}, j=1, \ldots, n ; i=1, \ldots, m
$$

c) Create the weighted normalized performance matrix.

A set of weights $w=\left(w_{1}, w_{2}, \ldots w_{n}\right), \sum_{j=1}^{n} w_{j}=1$, from the AHP is the accommodated weight. This matrix can be calculated by multiplying each column of $R$ by its associated weight $w_{j}$. Therefore, the weighted normalized decision matrix is denoted by $V$ :

$$
V=\left[\begin{array}{cccccc}
V_{11} & V_{12} & \cdots & V_{1 j} & \cdots & V_{1 n} \\
\vdots & \vdots & & \vdots & & \vdots \\
V_{i 1} & V_{i 2} & \cdots & V_{i j} & \cdots & V_{i n} \\
\vdots & \vdots & & \vdots & & \vdots \\
V_{m 1} & V_{m 2} & \cdots & V_{m j} & \cdots & V_{m n}
\end{array}\right]=\left[\begin{array}{cccccc}
w_{1} r_{11} & w_{2} r_{12} & \cdots & w_{j} r_{i j} & \cdots & w_{n} r_{1 n} \\
\vdots & \vdots & & \vdots & & \vdots \\
w_{1} r_{i 1} & w_{2} r_{i 2} & \cdots & w_{j} r_{i j} & \cdots & w_{n} r_{i n} \\
\vdots & \vdots & & \vdots & & \vdots \\
w_{1} r_{m 1} & w_{2} r_{m 2} & \cdots & w_{j} r_{m j} & \cdots & w_{n} r_{m n}
\end{array}\right]
$$

d) Determine the ideal solution and negative ideal solution.

The ideal solution is computed using the following equations:

$$
\begin{aligned}
& A^{*}=\left\{\left(\max V_{i j} \mid j \in J\right),\left(\min V_{i j} \mid j \in J^{\prime}\right), i=1,2, \ldots, m\right\}, \\
& A^{-}=\left\{\left(\min V_{i j} \mid j \in J\right),\left(\max V_{i j} \mid j \in J^{\prime}\right), i=1,2, \ldots, m\right\},
\end{aligned}
$$

where $j=\{j=1,2, \ldots, n \mid j$ belongs to benefit criteria $\}, j^{\prime}=\{j=1,2, \ldots, n \mid j$ belongs to cost criteria\}. 
e) Calculate the distance between the ideal solution and the negative ideal solution for each alternative as follows:

$$
\begin{aligned}
& S_{i}^{*}=\sqrt{\sum_{j=1}^{n}\left(V_{i j}-V_{j}^{*}\right)^{2}} \quad i=1,2, \ldots, m ; \\
& S_{i}^{-}=\sqrt{\sum_{j=1}^{n}\left(V_{i j}-V_{j}^{-}\right)^{2}} \quad i=1,2, \ldots, m .
\end{aligned}
$$

f) Calculate the relative closeness to the ideal solution for each alternative:

$$
C_{i}^{*}=\frac{S_{i}^{-}}{S_{i}^{*}+S_{i}^{-}} i=1,2, \ldots, m,
$$

where: $0 \leq C_{i}^{*} \leq 1$; that is, an alternative $i$ is closer to $A^{*}$ as $C_{i}^{*}$ approaches 1 .

g) A set of alternatives can be preference-ranked according to the descending order of $C_{i}^{*}$.

\section{The VIKOR method}

The VIKOR method was proposed by Opricovic and Tzeng (2004). The basic concept of the VIKOR method is based on the compromise programming utilized in MCDM by comparing the measure of "closeness" to the "ideal" alternative (Opricovic, Tzeng 2004; Baležentis et al. 2012). The various alternatives are denoted by $a_{1}, a_{2} \ldots, a_{m}$. For an alternative $a_{i}$, the merit of the jth aspect is denoted by $f_{i j}$, that is, $f_{i j}$ is the value of the $j$ th criterion function for the alternative $a_{i}$.

The compromise ranking algorithm is summarized as follows (Opricovic, Tzeng 2004; Wu et al. 2009a; Kuo, Liang 2011):

Step 1: Determine the best $f_{j}^{*}$ and the worst $f_{j}^{-}$values of all criterion functions. Assume that the $j$ th criterion function represents a benefit:

$$
f_{j}^{\star}=\max _{i} f_{i j}, \quad i=1,2,3, \ldots, m, \quad f_{j}^{-}=\min _{i} f_{i j}, \quad i=1,2,3, \ldots, m,
$$

Step 2: Compute the values $S_{i}$ and $R_{i}, i=1,2,3 \ldots, m$, by the relations:

$$
\begin{gathered}
S_{i}=\sum_{j=1}^{n} w_{j}\left(f_{j}^{*}-f_{i j}\right) /\left(f_{j}^{*}-f_{j}^{-}\right) ; \\
R_{i}=\max _{j}\left[w_{j}\left(f_{j}^{*}-f_{i j}\right) /\left(f_{j}^{*}-f_{j}^{-}\right)\right],
\end{gathered}
$$

where: $w_{j}$ is the weight of the $j$ th criteria, expressing the DM's preference in terms of the relative importance of the criteria.

Step 3: Compute the values $Q_{i}$ for $i=1,2,3, \ldots, m$, which are defined as:

$$
Q_{i}=v\left[\frac{S_{i}-S^{*}}{S^{-}-S^{*}}\right]+(1-v)\left[\frac{R_{i}-R^{*}}{R^{-}-R^{*}}\right],
$$

where: $S^{*}=\min _{i} S_{i}, S^{-}=\max _{i} S_{i}, R^{*}=\min _{i} R_{i}, R^{-}=\max _{i} R_{i}$, and $v$ is a weighting reference, $v$ is introduced as the weight of the strategy of the maximum group utility, whereas 
$(1-v)$ is the weight of the individual regret. Thus, when the $v$ reference is larger $(>0.5)$, the index of $Q_{i}$ will tend toward majority rule.

Step 4: Compute a compromise solution in which the alternative $\left(a^{\prime}\right)$ is ranked the best by the measure $Q$ (minimum) if it satisfies the following two conditions:

1. $Q\left(a^{\prime \prime}\right)-Q\left(a^{\prime}\right) \geq D Q$, which is called an "acceptable advantage".

In this equation, $a^{\prime \prime}$ is the alternative with the second position in the ranking list according to $D Q=1 /(J-1)$. $J$ is the number of alternatives;

2. The decision-making process demonstrates acceptable stability. Alternative $d$ must also be ranked the best by $S$ and/or $R$. This solution is stable in a decision-making process, which could consist of "voting by majority rule" (when $v>0.5$ is needed), "by consensus" $v \approx 0.5$, or "with veto" ( $v<0.5)$. Here, $v$ is the weight of the decision-making strategy with the max group utility.

If conditions are not fully satisfied, then a set of compromise solutions is proposed, as shown by the following two alternatives:

1. Alternatives $a^{\prime}$ and $a^{\prime \prime}$ are used only if condition 2 is not satisfied;

2. Alternatives $a^{\prime} ; a^{\prime \prime}, \ldots, a^{(M)}$ are used if condition 1 is not satisfied. $a^{(M)}$ is determined by the relation $Q\left(a^{(M)}\right)-Q\left(a^{\prime}\right)<D Q$ for maximum $M$.

The best alternative, ranked by $Q$, is the one with the minimum value of $Q$; the main ranking result is the compromise ranking list of alternatives and the compromise solution with the advantage rate (Tzeng et al. 2002; Opricovic, Tzeng 2004).

Ranking obtained by the VIKOR method requires the use of different values of the criteria weights and an analysis of the impact of the criteria weights on the proposed compromise solution. We determine the weight stability intervals by using the methodology presented in Opricovic (1998). The compromise solution gained with the initial weights $\left(w_{i}, i=1, \ldots, n\right)$ will be replaced if the value of a weight is missing from the stability interval. The analysis of the weight stability intervals for a single criterion is utilised for all criterion functions with the initial values of the weights. By doing so, the stability of the preferences in a gained compromise solution may be analysed utilising the VIKOR program (Opricovic, Tzeng 2004).

VIKOR is a tool that benefits MCDM in situations where the decision maker is unstable at the beginning of the system's design. In addition, decision makers accept the compromise solution because it provides a maximum group utility, which is represented by Min $Q$ and a minimum individual regret, which is represented by Min $R$ (Tzeng et al. 2002).

\section{Fuzzy AHP method}

Fuzzy set theory was introduced by Zadeh in 1965. As an important concept applied in the scientific environment, it has been made available to other fields as well (Wu et al. 2009a; Arslan, Aydin 2009). Fuzzy set theory is an important method used to measure the ambiguity of concepts that are associated with human beings' subjective judgments including linguistic terms $s^{3}$, degree of satisfaction and degree of importance that are often vague (Secme et al.

\footnotetext{
A linguistic variable is a variable whose values are not numbers but phrases in a natural language. For example, lingual expressions, such as satisfied, fair, and dissatisfied, are usually regarded as natural representations of humans' preferences or judgments (Zimmermann 1991; Herrera, Herrera-Viedma 2000; Secme et al. 2009).
} 
2009). AHP is one of the well-known MCDM techniques (Saaty 1980). Although classical AHP includes the opinions of experts and involves a multiple criteria evaluation, it is not capable of reflecting the vague thoughts of humans. Therefore, FAHP should be more appropriate and effective than conventional AHP in actual practice where an uncertain pairwise comparison environment exists (Gumus 2009; Baležentis et al. 2012; Chen 2012).

There are many FAHP methods proposed by various authors (Buckley 1985; Chang 1996; Deng 1999; Mikhailov 2004). In this study, we prefer Chang's (1996) extent analysis method (EAM) because the steps of this approach can be more easily applied than the other FAHP approaches (Büyüközkan et al. 2008; Celik et al. 2009; Choudhary, Shankar 2012; Sevkli et al. 2012). Let $X=\left\{x_{1}, x_{2}, \ldots, x_{n}\right\}$ be an object set, and $U=\left\{u_{1}, u_{2} \ldots, u_{m}\right\}$ be a goal set. Each object is taken and extent analysis for each goal is performed, respectively. Therefore, $m$ extent analysis values for each object can be obtained, with the following signs: $M_{g i}^{1}, M_{g i}^{2}, \ldots M_{g i}^{m}$, $i=1,2, \ldots, n$, where all the $M_{g i}^{j}(j=1,2, \ldots, m)$ are triangular fuzzy numbers (TFNs).

The steps for Chang's (1996) extent analysis can be given as follows (Gumus, 2009; Secme et al. 2009).

Step 1: The value of the fuzzy synthetic extent with respect to the $i$ th object is defined as:

$$
S_{i}=\sum_{j=1}^{m} M_{g i}^{j} \otimes\left[\sum_{i=1}^{n} \sum_{j=1}^{m} M_{g i}^{j}\right]^{-1}
$$

To obtain $\sum_{j=i}^{m} M_{g i}^{j}$ perform the fuzzy addition operation of $m$ extent analysis values for a particular matrix such that:

$$
\sum_{j=1}^{m} M_{g i}^{j}=\left(\sum_{j=1}^{m} l_{j}, \sum_{j=1}^{m} m_{j}, \sum_{j=1}^{m} u_{j}\right)
$$

Step 2: As $\tilde{M}_{2}$ and $\tilde{M}_{1}$ are two TFNs, the degree of possibility of $\tilde{M}_{2}=\left(l_{2}, m_{2}, u_{2}\right) \geq$ $\tilde{M}_{1}\left(l_{1}, m_{1}, u_{1}\right)$ is defined as:

$$
V\left(\tilde{M}_{2} \geq \tilde{M}_{1}\right)=\sup _{y \geq x}\left[\min \left(\mu_{M 1}(x), \mu_{M 2}(y)\right)\right]
$$

and can be equivalently expressed as follows:

$$
V\left(\tilde{M}_{2} \geq \tilde{M}_{1}\right)=\operatorname{hgt}\left(\tilde{M}_{1} \cap \tilde{M}_{2}\right)=\mu(d)=\left\{\begin{array}{l}
1, \quad \text { if } m_{2} \geq m_{1}, \\
0, \quad \text { if } l_{1} \geq u_{2}, \\
\frac{l_{1}-u_{2}}{\left(m_{2}-u_{2}\right)-\left(m_{1}-l_{1}\right)}, \text { otherwise, }
\end{array}\right.
$$

where $d$ is the ordinate of the highest intersection point $D$ between $\mu_{M_{1}}$ and $\mu_{M_{2}}$ (Fig. 1). 


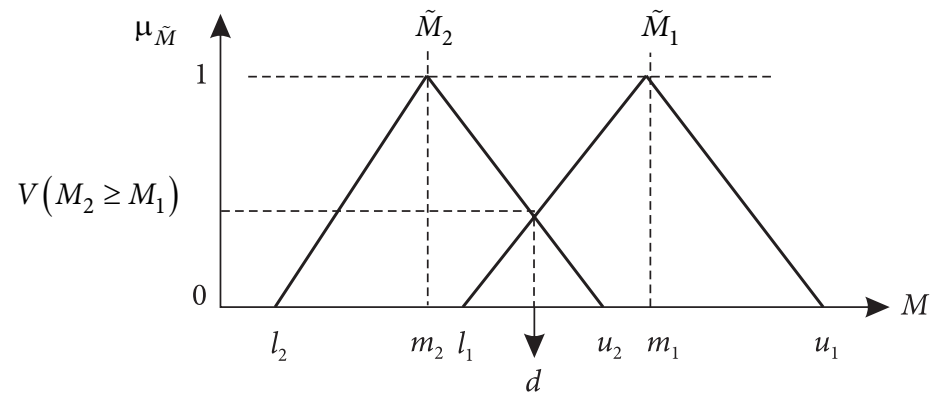

Fig. 1 . The intersection between $\mu_{1}$ and $\mu_{2}$

To compare $\tilde{M}_{2}$ and $\tilde{M}_{1}$, we need both values of $V\left(\tilde{M}_{1} \geq \tilde{M}_{2}\right)$ and $V\left(\tilde{M}_{2} \geq \tilde{M}_{1}\right)$.

Step 3: The degree of possibility for a convex fuzzy number to be greater than $k$ convex fuzzy numbers $\tilde{M}_{i}(i=1,2, \ldots, k)$ can be defined by:

$$
\begin{aligned}
V\left(\tilde{M} \geq \tilde{M}_{1}, \tilde{M}_{2}, \ldots, \tilde{M}_{k}\right) & =\left[V\left(\tilde{M} \geq \tilde{M}_{1}\right) \text { and }\left(\tilde{M} \geq \tilde{M}_{2}\right)\right] \text { and } \ldots \text { and } \\
\left(\tilde{M} \geq \tilde{M}_{k}\right) & =\min V\left(\tilde{M} \geq \tilde{M}_{i}\right), i=1,2,3, \ldots, k .
\end{aligned}
$$

Assume that $d^{\prime}\left(A_{i}\right)=\min V\left(S_{i} \geq S_{k}\right)$. For $k=1,2, \ldots, n ; k \neq i$. Then the weight vector is given by $W^{\prime}=\left(d^{\prime}\left(A_{1}\right), d^{\prime}\left(A_{2}\right), \ldots, d^{\prime}\left(A_{n}\right)\right)^{T}$, where $A_{i}(i=1,2, \ldots, n)$ comprises $n$ elements.

Step 4: Via normalization, the normalized weight vectors are $W=\left(d\left(A_{1}\right), d\left(A_{2}\right), \ldots\right.$, $\left.d\left(A_{n}\right)\right)^{T}$, where $W$ is a non-fuzzy number.

\section{An empirical study}

The four perspectives of BOCR are taken as the framework for establishing tablet PCs evaluation indicators in this study. Based on this research framework, we first use AHP to calculate the weights of the indicators and then utilize AHP-GRA, AHP-TOPSIS, and AHP-VIKOR to evaluate the tablet PC ranking based on the weight of each indicator. The study further applies FAHP to evaluate the ranking of tablet PCs. The hierarchical framework of the BOCR evaluation criteria and the resulting discussions are illustrated as follows.

\subsection{Hierarchical framework of the BOCR evaluation criteria}

Based on the four principles of evaluation (BOCR), experts' questionnaires were introduced to screen the indices' fit for the tablet PCs' evaluation and selection. Twenty-three evaluation indicators were selected by a committee of experts, comprising 21 professional experts from tablet PC-related industries including those engaged in $R \& D$, project management $(\mathrm{PM})$, marketing, procurement, and as touch product managers. Appendix Table A1 provides each supporting reference for the performance evaluation criteria and sub-criteria. Apple 


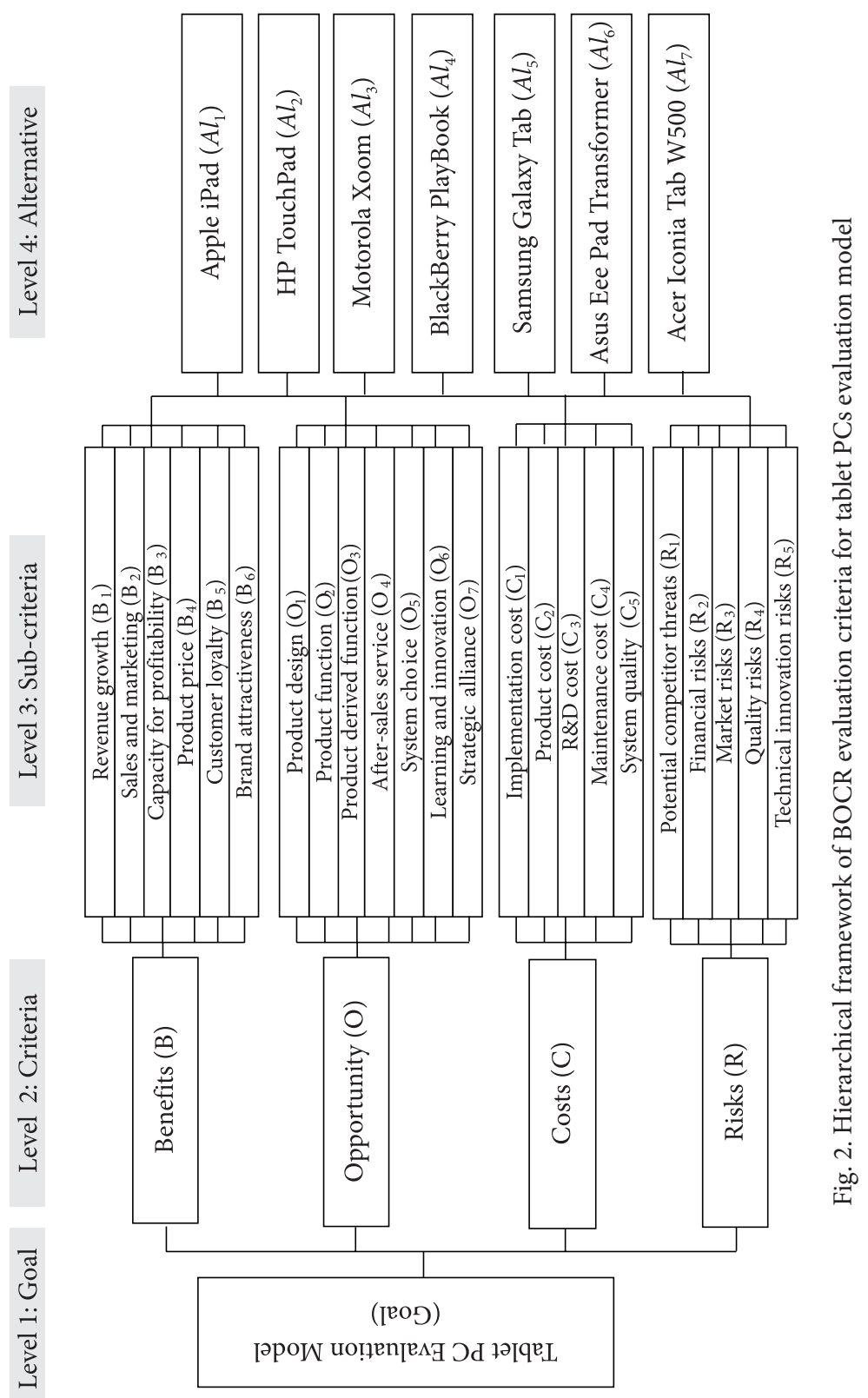


and Samsung are the top two leaders in the tablet PC industry, while HP, Asus and Acer are key leaders in the NB industry and Apple, Samsung, Motorola and BlackBerry are the main manufacturers in the smart phone industry. All of them produce tablet PCs. For this reason, we choose the following seven firms' tablet PC products as alternatives in this research: Apple iPad, HP TouchPad, Motorola Xoom, BlackBerry PlayBook, Samsung Galaxy Tab, Asus Eee Pad Transformer, and Acer Iconia Tab W500.

The hierarchical framework of the BOCR evaluation criteria (i.e. four dimensions and 23 indicators) for tablet PCs is shown in Figure 2. The four dimensions are ' $\mathrm{B}$ : Benefits $\left(\mathrm{B}_{1}-\mathrm{B}_{6}\right)$ ', 'O: Opportunity $\left(\mathrm{O}_{1}-\mathrm{O}_{7}\right)$ ', 'C: Costs $\left(\mathrm{C}_{1}-\mathrm{C}_{5}\right)$ ', and 'R: Risks $\left(\mathrm{R}_{1}-\mathrm{R}_{5}\right)$ '. Table A2 (the Appendix) provides a brief description of these seven alternatives among tablet PCs.

\subsection{Application of AHP in determining the weights of criteria}

Based on the hierarchical framework of the BOCR evaluation criteria and sub-criteria, the AHP questionnaire using the geometric mean method (GMM) was distributed among the 21 experts for soliciting their professional opinions. Table 1 describes the aggregate pairwise comparison matrix for the criteria; the sub-criteria are listed in Appendix Table A3. The relative importance scores of each evaluation indicator analysed by the AHP are listed in Table 2.

Table 1. Aggregate pairwise comparison matrix for criteria of level 2

\begin{tabular}{ccccc}
\hline Criteria & B & O & C & R \\
\hline B & 1.000 & 2.097 & 1.698 & 1.561 \\
O & 0.477 & 1.000 & 1.820 & 1.662 \\
C & 0.589 & 0.550 & 1.000 & 1.689 \\
R & 0.641 & 0.602 & 0.592 & 1.000 \\
\hline
\end{tabular}

Note: $\lambda_{\max }=4.150 ; \mathrm{CI}=0.050 ; \mathrm{RI}=0.900 ; \mathrm{CR}=0.056 \leq 0.1$.

Table 2. Weights of the BOCR evaluation index by AHP

\begin{tabular}{ccccc}
\hline \multirow{2}{*}{ Criteria } & $\begin{array}{c}\text { Weights for } \\
\text { level 2 }\end{array}$ & Sub-criteria & $\begin{array}{c}\text { Weights for } \\
\text { level 3 }\end{array}$ & $\begin{array}{c}\text { Weights of the } \\
\text { overall }\end{array}$ \\
\hline & & $\mathrm{B}_{1}$ & 0.213 & $0.079(1)$ \\
\cline { 3 - 5 } & 0.369 & $\mathrm{~B}_{2}$ & 0.168 & $0.062(3)$ \\
\cline { 3 - 5 } & & $\mathrm{B}_{3}$ & 0.193 & $0.071(2)$ \\
\cline { 3 - 5 } & & $\mathrm{B}_{4}$ & 0.159 & $0.059(4)$ \\
\cline { 3 - 5 } & & $\mathrm{B}_{5}$ & 0.125 & $0.046(10)$ \\
\cline { 3 - 5 } & 0.262 & $\mathrm{~B}_{6}$ & 0.142 & $0.052(7)$ \\
\cline { 3 - 5 } & & $\mathrm{O}_{1}$ & 0.209 & $0.055(5)$ \\
\cline { 3 - 5 } & & $\mathrm{O}_{2}$ & 0.151 & $0.040(12)$ \\
\cline { 3 - 5 } & & $\mathrm{O}_{3}$ & 0.121 & $0.032(16-17)$ \\
\hline & $\mathrm{O}_{4}$ & 0.110 & $0.029(20-21)$ \\
\hline
\end{tabular}


Continued Table 2

\begin{tabular}{|c|c|c|c|c|}
\hline Criteria & $\begin{array}{l}\text { Weights for } \\
\text { level } 2\end{array}$ & Sub-criteria & $\begin{array}{l}\text { Weights for } \\
\text { level } 3\end{array}$ & $\begin{array}{l}\text { Weights of the } \\
\text { overall }\end{array}$ \\
\hline & & $\mathrm{O}_{5}$ & 0.147 & $0.039(13)$ \\
\hline & & $\mathrm{O}_{6}$ & 0.123 & $0.032(16-17)$ \\
\hline & & $\mathrm{O}_{7}$ & 0.138 & $0.036(14)$ \\
\hline \multirow{5}{*}{$\mathrm{C}$} & \multirow{5}{*}{0.204} & $\mathrm{C}_{1}$ & 0.241 & $0.049(8)$ \\
\hline & & $\mathrm{C}_{2}$ & 0.231 & $0.047(9)$ \\
\hline & & $\mathrm{C}_{3}$ & 0.214 & $0.044(11)$ \\
\hline & & $\mathrm{C}_{4}$ & 0.162 & $0.033(15)$ \\
\hline & & $\mathrm{C}_{5}$ & 0.153 & $0.031(18-19)$ \\
\hline \multirow{5}{*}{$\mathrm{R}$} & \multirow{5}{*}{0.165} & $\mathrm{R}_{1}$ & 0.325 & $0.054(6)$ \\
\hline & & $\mathrm{R}_{2}$ & 0.191 & $0.031(18-19)$ \\
\hline & & $\mathrm{R}_{3}$ & 0.174 & $0.029(20-21)$ \\
\hline & & $\mathrm{R}_{4}$ & 0.147 & $0.024(23)$ \\
\hline & & $\mathrm{R}_{5}$ & 0.163 & $0.027(22)$ \\
\hline
\end{tabular}

Note: () denotes ranking order.

The results show that the critical order of the four BOCR dimensions for the evaluation of tablet PCs is "B: Benefits (0.369)", "O: Opportunity (0.262)", "C: Costs (0.204)", and "R: Risks $(0.165)$ ". Table 1 presents the respective weights of the six indicators for the "Benefits perspective, $B_{1}(0.213), B_{2}(0.168), B_{3}(0.193), B_{4}(0.159), B_{5}(0.125)$, and $B_{6}(0.142)$ ". The respective weights of the seven indicators for the "Opportunity perspective are $\mathrm{O}_{1}(0.209), \mathrm{O}_{2}(0.151)$, $\mathrm{O}_{3}(0.121), \mathrm{O}_{4}(0.110), \mathrm{O}_{5}(0.147), \mathrm{O}_{6}(0.123)$, and $\mathrm{O}_{7}(0.138)$ ". The respective weights of the five indicators for the "Costs perspective are $C_{1}(0.241), C_{2}(0.231), C_{3}(0.214), C_{4}(0.162)$, and $\mathrm{C}_{5}(0.153)$ ". The respective weights of the five indicators for the "Risks perspective are $\mathrm{R}_{1}(0.325), \mathrm{R}_{2}(0.191), \mathrm{R}_{3}(0.174), \mathrm{R}_{4}(0.147)$, and $\mathrm{R}_{5}(0.163)$ ).

The following are the synthesis values (overall weights) of the seven tablet PCs under the twenty-three indicators: $\mathrm{B}_{1}(0.079), \mathrm{B}_{2}(0.062), \mathrm{B}_{3}(0.071), \mathrm{B}_{4}(0.059), \mathrm{B}_{5}(0.046), \mathrm{B}_{6}(0.052), \mathrm{O}_{1}$ (0.055), $\mathrm{O}_{2}(0.040), \mathrm{O}_{3}(0.032), \mathrm{O}_{4}(0.029), \mathrm{O}_{5}(0.039), \mathrm{O}_{6}(0.032)$, and $\mathrm{O}_{7}(0.036), \mathrm{C}_{1}(0.049)$, $\mathrm{C}_{2}(0.047), \mathrm{C}_{3}(0.044), \mathrm{C}_{4}(0.033), \mathrm{C}_{5}(0.031), \mathrm{R}_{1}(0.054), \mathrm{R}_{2}(0.031), \mathrm{R}_{3}(0.029), \mathrm{R}_{4}(0.024)$, and $R_{5}(0.027)$. As indicated in Table 1 , the eight most important evaluation indicators are " $\mathrm{B}_{1}$ : Revenue growth (0.079)", " $\mathrm{B}_{3}$ : Capacity for profitability $(0.071)$ ", " $\mathrm{B}_{2}$ : Sales and marketing (0.062)", " $\mathrm{B}_{4}$ : Product price (0.059)", " $\mathrm{O}_{1}$ : Product design (0.055)", " $\mathrm{R}_{1}$ : Potential competitor threats (0.054)", " $\mathrm{B}_{6}$ : Brand attractiveness (0.052)", and " $\mathrm{C}_{1}$ : Implementation cost (0.049)".

\subsection{Application of AHP-GRA, AHP-TOPSIS, and AHP-VIKOR in ranking alternatives}

In this section, the GRA, TOPSIS, and VIKOR methods are introduced to rank the alternative performances. The priority weights of alternative performances with respect to the sub-criteria (decision matrix) calculated by AHP are shown in Table 3. 
Table 3. Weights of tablet PCs evaluation with respect to sub-criteria (decision matrix)

\begin{tabular}{|c|c|c|c|c|c|c|c|}
\hline Indicators & Apple & $\mathrm{HP}$ & Motorola & $\mathrm{BB}$ & Samsung & Asus & Acer \\
\hline $\mathrm{B}_{1}$ & 0.433 & 0.098 & 0.092 & 0.079 & 0.104 & 0.110 & 0.084 \\
\hline $\mathrm{B}_{2}$ & 0.449 & 0.100 & 0.093 & 0.072 & 0.108 & 0.098 & 0.079 \\
\hline $\mathrm{B}_{3}$ & 0.468 & 0.102 & 0.087 & 0.073 & 0.102 & 0.088 & 0.081 \\
\hline $\mathrm{B}_{4}$ & 0.370 & 0.103 & 0.101 & 0.090 & 0.127 & 0.117 & 0.092 \\
\hline $\mathrm{B}_{5}$ & 0.483 & 0.091 & 0.094 & 0.088 & 0.094 & 0.082 & 0.069 \\
\hline $\mathrm{B}_{6}$ & 0.493 & 0.083 & 0.091 & 0.087 & 0.094 & 0.076 & 0.076 \\
\hline $\mathrm{O}_{1}$ & 0.477 & 0.092 & 0.096 & 0.082 & 0.091 & 0.090 & 0.071 \\
\hline $\mathrm{O}_{2}$ & 0.408 & 0.098 & 0.091 & 0.095 & 0.108 & 0.113 & 0.088 \\
\hline $\mathrm{O}_{3}$ & 0.409 & 0.106 & 0.099 & 0.100 & 0.095 & 0.104 & 0.088 \\
\hline $\mathrm{O}_{4}$ & 0.341 & 0.113 & 0.109 & 0.090 & 0.113 & 0.116 & 0.117 \\
\hline $\mathrm{O}_{5}$ & 0.382 & 0.106 & 0.103 & 0.105 & 0.105 & 0.099 & 0.100 \\
\hline $\mathrm{O}_{6}$ & 0.454 & 0.088 & 0.089 & 0.080 & 0.102 & 0.111 & 0.076 \\
\hline $\mathrm{O}_{7}$ & 0.339 & 0.120 & 0.115 & 0.101 & 0.112 & 0.114 & 0.098 \\
\hline $\mathrm{C}_{1}$ & 0.409 & 0.105 & 0.087 & 0.090 & 0.116 & 0.101 & 0.093 \\
\hline $\mathrm{C}_{2}$ & 0.423 & 0.111 & 0.083 & 0.078 & 0.107 & 0.103 & 0.094 \\
\hline $\mathrm{C}_{3}$ & 0.436 & 0.098 & 0.104 & 0.101 & 0.103 & 0.084 & 0.075 \\
\hline $\mathrm{C}_{4}$ & 0.437 & 0.099 & 0.079 & 0.091 & 0.100 & 0.100 & 0.095 \\
\hline $\mathrm{C}_{5}$ & 0.425 & 0.103 & 0.092 & 0.088 & 0.099 & 0.100 & 0.093 \\
\hline $\mathrm{R}_{1}$ & 0.321 & 0.106 & 0.121 & 0.109 & 0.118 & 0.121 & 0.104 \\
\hline $\mathrm{R}_{2}$ & 0.299 & 0.130 & 0.125 & 0.112 & 0.120 & 0.112 & 0.101 \\
\hline $\mathrm{R}_{3}$ & 0.237 & 0.133 & 0.128 & 0.134 & 0.129 & 0.122 & 0.116 \\
\hline $\mathrm{R}_{4}$ & 0.255 & 0.116 & 0.109 & 0.118 & 0.139 & 0.134 & 0.128 \\
\hline $\mathrm{R}_{5}$ & 0.292 & 0.117 & 0.118 & 0.116 & 0.130 & 0.121 & 0.106 \\
\hline
\end{tabular}

I. Selection of the best tablet PCs by AHP-GRA

The weights are estimated by 21 experts with each of the respondents using Saaty's relative importance scale and averaging their scales to assess candidates, before establishing a decision making matrix as shown in Table 3.

The thirteen sub-criteria (for the "B" and "O" perspective) are 'the larger the better' and the ten sub-criteria (for the "C" and " $\mathrm{R}$ " perspective) are 'the smaller the better. Accordingly, the referential series can be $X_{0}=(0.433,0.449,0.468,0.370,0.483,0.493,0.477,0.408,0.409$, $0.341,0.382,0.454,0.339,0.087,0.078,0.075,0.079,0.088,0.104,0.101,0.116,0.109$, and 0.106). The tablet PCs are $X_{1}, X_{2}, X_{3}, X_{4}, X_{5}, X_{6}$, and $X_{7}$. Data are normalized for twenty-three sub-criteria by using Eqs. (1) and (2). Following the normalization of the data and the relational coefficients of the compared series, Table 4 reveals the result that the Apple iPad is the top one and is followed by the Samsung Galaxy Tab and the Asus Eee Pad Transformer. 
Table 4. The final evaluation and ranking of tablet PCs (Summary of the GRA $\Gamma_{0 i}$ )

\begin{tabular}{lcc}
\hline \multicolumn{1}{c}{ Tablet PCs selection } & $\Gamma_{0 i}$ & Ranking \\
\hline Apple $\left(\mathrm{Al}_{1}\right)$ & 1.000 & 1 \\
$\mathrm{HP}\left(\mathrm{Al}_{2}\right)$ & 0.348 & 4 \\
Motorola $\left(\mathrm{Al}_{3}\right)$ & 0.344 & 5 \\
$\mathrm{BB}\left(\mathrm{Al}_{4}\right)$ & 0.340 & 6 \\
Samsung $\left(\mathrm{Al}_{5}\right)$ & 0.352 & 2 \\
Asus $\left(\mathrm{Al}_{6}\right)$ & 0.348 & 3 \\
Acer $\left(\mathrm{Al}_{7}\right)$ & 0.338 & 7 \\
\hline
\end{tabular}

\section{Selection of the best tablet PCs by AHP-TOPSIS}

Based on the AHP-TOPSIS method, by using the decision, normalized, and weighted normalized decision matrices, Eqs. (4) and (5) determine the ideal solution and negative ideal solution (Table 5). Following the TOPSIS weights and the relative closeness to the ideal solution of each alternative, $C_{i}^{*}$ from Eq. (6), we have the performance ranking order of the seven tablet PCs as follows: Apple $\left(\mathrm{Al}_{1}\right)(1.000)>$ Samsung $\left(\mathrm{Al}_{5}\right)(0.074)>\mathrm{HP}$ $\left(\mathrm{Al}_{2}\right)(0.063)>$ Asus $\left(\mathrm{Al}_{6}\right)(0.061)>$ Motorola $\left(\mathrm{Al}_{3}\right)(0.050)>\mathrm{BB}\left(\mathrm{Al}_{4}\right)(0.031)>$ Acer $\left(\mathrm{Al}_{7}\right)$ (0.024) (Table 5).

Table 5. Final evaluation of the alternatives in TOPSIS

\begin{tabular}{lcccc}
\hline $\begin{array}{c}\text { Tablet PCs Selec- } \\
\text { tion }\end{array}$ & $S_{i}^{*}$ & $S_{i}^{-}$ & $C_{i}^{*}$ & Ranking \\
\hline Apple $\left(\mathrm{Al}_{1}\right)$ & 0.000 & 0.549 & 1.000 & 1 \\
$\mathrm{HP}\left(\mathrm{Al}_{2}\right)$ & 0.518 & 0.035 & 0.063 & 3 \\
Motorola $\left(\mathrm{Al}_{3}\right)$ & 0.527 & 0.028 & 0.050 & 5 \\
BB $\left(\mathrm{Al}_{4}\right)$ & 0.538 & 0.017 & 0.031 & 6 \\
Samsung $\left(\mathrm{Al}_{5}\right)$ & 0.511 & 0.041 & 0.074 & 2 \\
Asus $\left(\mathrm{Al}_{6}\right)$ & 0.519 & 0.034 & 0.061 & 4 \\
Acer $\left(\mathrm{Al}_{7}\right)$ & 0.542 & 0.014 & 0.024 & 7 \\
\hline
\end{tabular}

III. Selection of the best tablet PCs by AHP-VIKOR

The AHP-VIKOR approach ranks the performance of the seven tablet PCs based on the weights of the BOCR performance evaluation indicators by AHP as shown in Table 3. Table A4 (Appendix) shows the performance matrix given by Eq. (7) with the best value $f_{j}^{*}$ and the worst value $f_{j}^{-}$. The values of $S_{i}$ and $R_{i}$ by Eqs. (8) and (9) are shown in Table A5 (Appendix), while the computed value $Q_{i}$ (with $v=0,0.5,1$ ) using Eq. (10) and the preference order tablet PCs ranking are given in Table 6. 
Table 6 . The preference order ranking by VIKOR for sensitivity analysis

\begin{tabular}{lccc}
\hline Tablet PCs Selection & $Q_{i}[v=0]$ & $Q_{i}[v=0.5]$ & $Q_{i}[v=1]$ \\
\hline Apple $\left(\mathrm{Al}_{1}\right)$ & $0.000(1)$ & $0.000(1)$ & $0.000(1)$ \\
$\mathrm{HP}\left(\mathrm{Al}_{2}\right)$ & $0.987(6)$ & $0.971(5)$ & $0.955(3-4)$ \\
Motorola $\left(\mathrm{Al}_{3}\right)$ & $0.918(2)$ & $0.944(4)$ & $0.970(5)$ \\
$\mathrm{BB}\left(\mathrm{Al}_{4}\right)$ & $0.975(5)$ & $0.982(6)$ & $0.988(6)$ \\
Samsung $\left(\mathrm{Al}_{5}\right)$ & $0.933(4)$ & $0.936(2)$ & $0.938(2)$ \\
Asus $\left(\mathrm{Al}_{6}\right)$ & $0.919(3)$ & $0.937(3)$ & $0.955(3-4)$ \\
Acer $\left(\mathrm{Al}_{7}\right)$ & $1.000(7)$ & $1.000(7)$ & $1.000(7)$ \\
\hline
\end{tabular}

Note: () denotes ranking order.

The final ranking result is judged and produced according to two cardinal conditions (C1 and C2) stated in Section 1.2 (Wu et al. 2011b). The judging methods are as follows:

\section{C1. "Acceptable advantage":}

In this study (which postulates that $v=0.5)$, the $D Q$ threshold value is $0.167(D Q=1 /$ $(7-1)=0.167)$. According to the $Q_{i}$ value in Table 6, the gap between the ranked first Apple $(0.000)$ and ranked second Samsung $(0.936)$ is 0.936 . Since 0.936 surpasses the acceptable profit threshold value 0.167 , it meets the acceptable profit threshold of condition one (C1). Besides, the gap of the $Q_{i}$ value between the ranked second Samsung (0.936) and ranked third Asus (0.937) is 0.001 less than 0.167 therefore it does not meet the condition one (C1). Then, the gap of the $Q_{i}$ value between the ranked third Asus (0.937) and the ranked fourth Motorola (0.944) is 0.007 , which does not fit in with the condition one (C1). The acceptable profit threshold of condition one (C1) does not be satisfied, while the gap of the $Q_{i}$ value between the ranked fourth Motorola (0.944) and the ranked fifth $\mathrm{HP}(0.971)$ is $0.027(<0.167)$. The gap of the $Q_{i}$ value between the ranked fifth $\mathrm{HP}(0.971)$ and the ranked sixth $\mathrm{BB}(0.982)$ is $0.011(<0.167)$ which does not fit in with the acceptable profit threshold of condition one (C1). Finally, the gap of the $Q_{i}$ value between the ranked sixth $\mathrm{BB}(0.982)$ and the ranked seventh Acer $(1.000)$ is $0.018(<0.167)$. That is, the gap does not be satisfy condition one $(\mathrm{C} 1)$.

\section{C2. "Acceptable stability in decision making":}

As Table A5 (Appendix) shows, the $S_{i}$ value and the $R_{i}$ value of the ranked first Apple in the $Q_{i}$ value are superior to those of the ranked other tablet PCs which confirms to the reliability of the analysis of the acceptable policy of condition two (C2).

Based on the analysis results of the above two conditions, we have that Apple $>$ Samsung $\approx$ Asus $\approx$ Motorola $\approx \mathrm{HP} \approx \mathrm{BB} \approx$ Acer . Consequently, Apple is superior to the other six tablet PCs. Apple should be the preferred choice because it has the "best relative weights". 


\subsection{Application of fuzzy AHP on tablet PCs evaluation and selection problem}

In FAHP, firstly, the main criteria, sub-criteria, and the importance weights of alternatives must be compared. For this reason, there must be linguistic terms and their equivalent fuzzy numbers denoting comparison measures. The linguistic comparison terms and their equivalent fuzzy numbers considered in this study are shown in Table 7.

Table 7. Membership function of linguistic scale

\begin{tabular}{clcc}
\hline Fuzzy Number & Linguistic Scale & Triangular Fuzzy Scale & Inverse of Triangular Fuzzy Scale \\
\hline$\tilde{1}$ & Equal & $(1,1,1)$ & $(1,1,1)$ \\
$\tilde{2}$ & Weak advantage & $(1,2,3)$ & $(1 / 3,1 / 2,1)$ \\
$\tilde{3}$ & Not bad & $(2,3,4)$ & $(1 / 4,1 / 3,1 / 2)$ \\
$\tilde{4}$ & Preferable & $(3,4,5)$ & $(1 / 5,1 / 4,1 / 3)$ \\
$\tilde{5}$ & Good & $(4,5,6)$ & $(1 / 6,1 / 5,1 / 4)$ \\
$\tilde{6}$ & Fairly good & $(5,6,7)$ & $(1 / 7,1 / 6,1 / 5)$ \\
$\tilde{7}$ & Very good & $(6,7,8)$ & $(1 / 8,1 / 7,1 / 6)$ \\
$\tilde{8}$ & Absolute & $(7,8,9)$ & $(1 / 9,1 / 8,1 / 7)$ \\
$\tilde{9}$ & Perfect & $(8,9,10)$ & $(1 / 10,1 / 9,1 / 8)$ \\
\hline
\end{tabular}

The weights of the criteria and sub-criteria are determined by FAHP. The pairwise comparison scores were carried out by 21 experts working in $R \& D$, project management (PM), marketing, procurement, and as touch product managers in the tablet PC industry. The fuzzy pairwise comparisons matrix for the goal is presented in Table A6 (Appendix).

The values of fuzzy synthetic extents with respect to the goal were computed using Eq. (11) as follows:

$$
\begin{aligned}
& S_{B}=(5.220,6.356,7.583) \otimes(1 / 26.619,1 / 17.977,1 / 14.863)=(0.241,0.354,0.510) ; \\
& S_{O}=(3.996,4.959,6.007) \otimes(1 / 26.619,1 / 17.977,1 / 14.863)=(0.185,0.276,0.404) ; \\
& S_{C}=(3.187,3.828,4.647) \otimes(1 / 26.619,1 / 17.977,1 / 14.863)=(0.147,0.213,0.313) ; \\
& S_{R}=(2.459,2.834,3.382) \otimes(1 / 26.619,1 / 17.977,1 / 14.863)=(0.114,0.158,0.228) .
\end{aligned}
$$

The synthetic values obtained were compared by using Eq. (12) and the following results were obtained:

Comparison of $S_{B}$ with the others: $V\left(S_{B} \geq S_{O}\right)=1, V\left(S_{B} \geq S_{C}\right)=1, V\left(S_{B} \geq S_{R}\right)=1$. Comparison of $S_{O}$ with the others: $V\left(S_{O} \geq S_{B}\right)=0.667, V\left(S_{O} \geq S_{C}\right)=1, V\left(S_{O} \geq S_{R}\right)=1$.

Comparison of $S_{C}$ with the others: $V\left(S_{C} \geq S_{B}\right)=0.336, V\left(S_{C} \geq S_{O}\right)=0.670$, $V\left(S_{C} \geq S_{R}\right)=1$. Comparison of $S_{R}$ with the others: $V\left(S_{R} \geq S_{B}\right)=0.076, V\left(S_{R} \geq S_{O}\right)=0.265$, $V\left(S_{R} \geq S_{C}\right)=0.592$.

The priority weights were subsequently calculated as follows:

$$
\begin{aligned}
& d^{\prime}\left(S_{B}\right)=\min V\left(S_{B} \geq S_{O}, S_{C}, S_{R}\right)=1 ; d^{\prime}\left(S_{O}\right)=\min V\left(S_{O} \geq S_{B}, S_{C}, S_{R}\right)=0.677 ; \\
& d^{\prime}\left(S_{C}\right)=\min V\left(S_{C} \geq S_{B}, S_{O}, S_{R}\right)=0.336 ; d^{\prime}\left(S_{R}\right)=\min V\left(S_{R} \geq S_{B}, S_{O}, S_{C}\right)=0.076 .
\end{aligned}
$$


The weights vector is $W_{\text {goal }}^{\prime}=(1,0.677,0.336,0.076)^{T}$. After the normalization, the nor malized weight vector with respect to the goal is $W_{\text {goal }}=(0.479,0.324,0.161,0.036)^{T}$. In a similar way, following the fuzzy pairwise comparisons matrix for the sub-criteria, the weights of importance of sub-criteria with BOCR should be calculated respectively as shown in Table A7 (Appendix).

Finally, the performance ranking order of the seven tablet PCs using FAHP is Apple $\left(\mathrm{Al}_{1}\right)$ $(0.210)>$ Samsung $\left(\mathrm{Al}_{5}\right)(0.142)>\mathrm{HP}\left(\mathrm{Al}_{2}\right)(0.140)>$ Motorola $\left(\mathrm{Al}_{6}\right)(0.133)>$ Asus $\left(\mathrm{Al}_{3}\right)$ $(0.128)>\mathrm{BB}\left(\mathrm{Al}_{4}\right)(0.126)>\operatorname{Acer}\left(\mathrm{Al}_{7}\right)(0.122)$ as shown in Table 8. The final values and preference order ranking for these four MCDM models, namely, AHP-GRA, AHP-TOPSIS, AHP-VIKOR, and FAHP, are summarized in Table 9.

Table 8. Summary of priority weights of the tablet PCs with respect to each criterion by FAHP

\begin{tabular}{ccccccc}
\hline & B & O & C & R & $\begin{array}{c}\text { Alternative } \\
\text { priority weight }\end{array}$ & $\begin{array}{c}\text { Rank- } \\
\text { ing }\end{array}$ \\
\hline $\mathrm{w}$ & 0.479 & 0.324 & 0.161 & 0.036 & & \\
Apple $\left(\mathrm{Al}_{1}\right)$ & 0.207 & 0.199 & 0.197 & 0.397 & 0.210 & 1 \\
HP $\left(\mathrm{Al}_{2}\right)$ & 0.144 & 0.139 & 0.137 & 0.099 & 0.140 & 3 \\
Motorola $\left(\mathrm{Al}_{3}\right)$ & 0.130 & 0.140 & 0.140 & 0.069 & 0.133 & 4 \\
BB $\left(\mathrm{Al}_{4}\right)$ & 0.119 & 0.134 & 0.132 & 0.120 & 0.126 & 6 \\
Samsung $\left(\mathrm{Al}_{5}\right)$ & 0.151 & 0.139 & 0.134 & 0.086 & 0.142 & 2 \\
Asus $\left(\mathrm{Al}_{6}\right)$ & 0.125 & 0.133 & 0.135 & 0.087 & 0.128 & 5 \\
Acer $\left(\mathrm{Al}_{7}\right)$ & 0.124 & 0.116 & 0.125 & 0.142 & 0.122 & 7 \\
\hline
\end{tabular}

Table 9. Summary of preference order ranking by four MCDM methods

\begin{tabular}{lcccc}
\hline Tablet PCs selection & AHP-GRA & AHP-TOPSIS & AHP-VIKOR & FAHP \\
\hline Apple $\left(\mathrm{Al}_{1}\right)$ & $1.000(1)$ & $1.000(1)$ & $0.000(1)$ & $0.210(1)$ \\
$\mathrm{HP}\left(\mathrm{Al}_{2}\right)$ & $0.348(4)$ & $0.063(3)$ & $0.971(5)$ & $0.140(3)$ \\
Motorola $\left(\mathrm{Al}_{3}\right)$ & $0.344(5)$ & $0.050(5)$ & $0.944(4)$ & $0.133(4)$ \\
BB $\left(\mathrm{Al}_{4}\right)$ & $0.340(6)$ & $0.031(6)$ & $0.982(6)$ & $0.126(6)$ \\
Samsung $\left(\mathrm{Al}_{5}\right)$ & $0.352(2)$ & $0.074(2)$ & $0.936(2)$ & $0.142(2)$ \\
Asus $\left(\mathrm{Al}_{6}\right)$ & $0.348(3)$ & $0.061(4)$ & $0.937(3)$ & $0.128(5)$ \\
Acer $\left(\mathrm{Al}_{7}\right)$ & $0.338(7)$ & $0.024(7)$ & $1.000(7)$ & $0.122(7)$ \\
\hline
\end{tabular}

Note: () denotes ranking order.

\subsection{Discussions}

This study conducted a performance analysis for the top seven tablet PCs using a MCDM approach based on the BOCR perspectives. The four MCDM models (i.e. AHP-GRA, AHP-TOPSIS, AHP-VIKOR, and FAHP) were employed in the performance analysis to 
compute the weights of the criteria, ranking the tablet PCs' performance and attempting to explain the differences among the seven tablet PCs, respectively.

Based on the empirical results, we find that the Apple iPad has the highest value among the seven tablet PCs for the four MCDM models (i.e. AHP-GRA (1.000), AHP-TOPSIS (1.000), AHP-VIKOR (0.000), and FAHP (0.210)); the Samsung Galaxy Tab has the second highest value (i.e. AHP-GRA (0.352), AHP-TOPSIS (0.074), AHP-VIKOR (0.936), and FAHP (0.142)); and the Acer Iconia Tab W500 is the last with the lowest weight (i.e. AHP-GRA (0.338), AHP-TOPSIS (0.024), AHP-VIKOR (1.000), and FAHP (0.122)). As shown in Table 1 and Table A5, the results of the AHP and FAHP analysis reveal that the "benefits" perspective $\left(W_{\mathrm{AHP}}(0.369) ; W_{\text {FAHP }}(0.479)\right)$ and "opportunity" perspective $\left(W_{\mathrm{AHP}}(0.262) ; W_{\mathrm{FAHP}}(0.324)\right)$ have higher weightings. Revenue growth, the capacity for profitability, product design, and product function are most important evaluation indicators in terms of benefits and opportunity, respectively. This is because tablet PCs are part of the consumer electronics (CE) industry, and the performance of tablet PCs is strongly connected to revenue growth, the capacity for profitability, product design, and product function. Sales and marketing, product price, systems choice, and strategic alliances are the other most important indicators for sustaining a high tablet PC market performance.

In Consumer Reports (2012), the 2012 best tablet PCs evaluation indicated that the Apple iPad was the best tablet PC among all tablet PCs. There are two key factors to make the Apple iPad a success. First, the iPad follows other successful devices in the market by offering a complete solution that includes the device, the wireless service, and the content. The second reason is that the iPad finds the right combination of new technology, content, applications, and services that provide a unique usage experience and then combine it with the appropriate business model. Obviously, how to find a right business model for monetizing a device, connectivity and content has become the first priority in successfully launching new platforms in the tablet PC industry. For instance, the Apple iPad has created a new market with promising growth opportunities and logically new players must appear. However, Apple has a unique strategy of addressing the mass-market at a premium price and with a design based in its brand strength, setting the new rules and standards for this new market. In addition, the Apple iPad's biggest competitive advantage is the "content controllability" based on the iTunes and Apps Store, which no other competitor will have in the short-term.

\section{Conclusions and implications}

This study adopts the MCDM point of view to construct the Tablet PCs performance evaluation model based on the BOCR conceptual framework. The chief advantage of this research is that it can be used for both qualitative and quantitative criteria (Wu et al. 2010). Systematic approaches using AHP-GRA, AHP-TOPSIS, AHP-VIKOR, and Fuzzy AHP have been applied in Tablet PC performance evaluation.

The empirical findings of this research can be summarized as follows. First, by integrating all the relevant literature reviews and experts' opinions, 23 indicators are selected as being suitable for the Tablet PCs' performance in terms of four perspectives, namely, the benefits, opportunity, costs, and risks. Secondly, the weights of the AHP criteria reveal that the ranking of the Tablet PCs' performance of the seven main Tablet PCs by employing the GRA, 
TOPSIS, VIKOR and FAHP methods is as shown in Table 8. In particular, the Apple iPad and Samsung Galaxy Tab are the top two based on the four MCDM methods while the Acer Iconia W500 (AHP-GRA) comes last.

We hope the four MCDM models in this study could be helpful to Tablet PC company managers and other decision makers for creating a more effective performance evaluation system. For example, the results of the AHP and FAHP analysis reveal that the "benefits" perspective and "opportunity" perspective are the two most important criteria. Revenue growth, the capacity for profitability, product design, and product function are highly important evaluation indicators. This indicates that Tablet PC companies should expend more effort on their product innovation for creating revenue growth and maintaining customer loyalty. They should also provide more product functions and fun features on their Tablet PC products. After observing the iPad's success, some PC manufacturers such as HP, Asus, Dell, and Microsoft have announced the launch of their new Tablet PCs by the end of 2012. In addition, Google-Android and Windows RT or 8 are becoming a big threat due to their large numbers of applications being created and their high performance OS. Most of the key competitors (such as Samsung and Microsoft) in the Tablet PCs market must launch their products with additional features in order to increase their own competitive advantage in the future.

Of course, this study provides two important criteria and sub-criteria for the Tablet PCs performance evaluation based on this concept of MCDM. In a future study, we could utilize the fuzzy analytic network process (Fuzzy ANP) with decision making trials and an evaluation laboratory to discuss the interactive and feedback relationships among indexes of the BOCR to enrich the research on the Tablet PC industry.

\section{Acknowledgements}

The authors are grateful to the editor and anonymous referees for their valuable comments and suggestions which helped in improving the quality of this paper.

\section{References}

Amiri, M.; Zandieh, M.; Soltani, R.; Vahdani, B. 2009. A hybrid multi-criteria decision-making model for firms competence evaluation, Expert Systems with Applications 36(10): 12314-12322. http://dx.doi.org/10.1016/j.eswa.2009.04.045

Arslan, G.; Aydin, Ö. 2009. A new software development for Fuzzy Multicriteria decision-making, Technological and Economic Development of Economy 15(2): 197-212. http://dx.doi.org/10.3846/1392-8619.2009.15.197-212

Baležentis, A.; Baležentis, T.; Misiunas, A. 2012. An integrated assessment of Lithuanian economic sectors based on financial ratios and fuzzy MCDM methods, Technological and Economic Development of Economy 18(1): 34-53. http://dx.doi.org/10.3846/20294913.2012.656151

Bentes, A. V.; Carneiro, J.; Ferreira da Silva, J.; Kimura, H. 2012. Multidimensional assessment of organizational performance: integrating BSC and AHP, Journal of Business Research 65(12): 1790-1799. http://dx.doi.org/10.1016/j.jbusres.2011.10.039

Birgelen, M. V.; Ruyter, K. D.; Jong, A. D.; Wetzels, M. 2002. Customer evaluations of after-sales service contact modes: an empirical analysis of national culture's consequences, International Journal of Research in Marketing 19(1): 43-64. http://dx.doi.org/10.1016/S0167-8116(02)00047-2 
Buckley, J. J. 1985. Fuzzy hierarchical analysis, Fuzzy Sets and Systems 17(3): 233-247. http://dx.doi.org/10.1016/0165-0114(85)90090-9

Büyüközkan, G.; Çifçi, G.; Güleryüz, S. 2011. Strategic analysis of healthcare service quality using fuzzy AHP methodology, Expert Systems with Applications 38(8): 9407-9424. http://dx.doi.org/10.1016/j.eswa.2011.01.103

Büyüközkan, G.; Feyzloğlu, O.; Nebol, E. 2008. Selection of the strategic alliance partner in logistics value chain, International Journal of Production Economics 113(1): 148-158. http://dx.doi.org/10.1016/j.ijpe.2007.01.016

Cebeci, U. 2009. Fuzzy AHP-based decision support system for selecting ERP systems in textile industry by using balanced scorecard, Expert Systems with Applications 36(5): 8900-8909. http://dx.doi.org/10.1016/j.eswa.2008.11.046

Celik, M.; Er, D. I.; Ozok, A. F. 2009. Application of fuzzy extended AHP methodology on shipping registry selection: The case of Turkish maritime industry, Expert Systems with Applications 36(1): 190-198. http://dx.doi.org/10.1016/j.eswa.2007.09.004

Chan, F. T. S.; Kumar, N. 2007. Global supplier development considering risk factors using fuzzy extended AHP-based approach, Omega 35(4): 417-431. http://dx.doi.org/10.1016/j.omega.2005.08.004

Chan, S. L.; Ip, W. H.; Cho, V. 2010. A model for predicting customer value from perspectives of product attractiveness and marketing strategy, Expert Systems with Applications 37(2): 1207-1215. http://dx.doi.org/10.1016/j.eswa.2009.06.030

Chang, D. Y. 1996. Applications of the extent analysis method on fuzzy AHP, European Journal of Operational Research 95(3): 649-655. http://dx.doi.org/10.1016/0377-2217(95)00300-2

Chen, H. H.; Lee, A. H. I.; Kang, H. Y. 2010a. A model for strategic selection of feeder management systems: A case study, Electrical Power and Energy Systems 32(5): 421-427.

http://dx.doi.org/10.1016/j.ijepes.2009.09.023

Chen, H. S.; Wang, P. W.; Chen, C. M.; Lee, H. T. 2010b. An analytic hierarchy process approach with linguistic variables for selection of an R\&D strategic alliance partner, Computers \& Industrial Engineering 58(2): 278-287. http://dx.doi.org/10.1016/j.cie.2009.10.006

Chen, J. K. 2012. The assessment of vision re-creation indices for the automotive industry in Taiwan: a hybrid fuzzy model approach, Measurement 45(5): 909-917. http://dx.doi.org/10.1016/j.measurement.2012.02.004

Choudhary, D.; Shankar, R. 2012. A STEEP-fuzzy AHP-TOPSIS framework for evaluation and selection of thermal power plant location: a case study from India, Energy 42(1): 510-521. http://dx.doi.org/10.1016/j.energy.2012.03.010

Consumer Reports. 2012. [online], [cited 6 November 2013]. Available from Internet: http://www.consumersearch.com/tablet-computers/review

Cook, W. D.; Hababou, M. 2001. Sales performance measurement in bank branches, Omega 29(4): 299-307. http://dx.doi.org/10.1016/S0305-0483(01)00025-1

Cox, M. A. A. 2012. Which is the appropriate triangular distribution to employ in the modified analytic hierarchy process?, IMA Journal of Management Mathematics 23(3): 227-239. http://dx.doi.org/10.1093/imaman/dpr012

Deng, H. 1999. Multicriteria analysis with fuzzy pairwise comparison, International Journal of Approximate Reasoning 21(3): 215-231. http://dx.doi.org/10.1016/S0888-613X(99)00025-0

Deng, J. L. 1982. Control problems of grey system, Systems and Control letters 1(5): 288-294. http://dx.doi.org/10.1016/S0167-6911(82)80025-X

Deng, Z.; Lu, Y.; Wei, K. K.; Zhang, J. 2010. Understanding customer satisfaction and loyalty: an empirical study of mobile instant messages in China, International Journal of Information Management 30(4): 289-300. http://dx.doi.org/10.1016/j.ijinfomgt.2009.10.001 
Eroğmuş, Ş.; Kapanoglu, M.; Koç, E. 2005. Evaluating high-tech alternatives by using analytic network process with BOCR and multiactors, Evaluation and Program Planning 28(4): 391-399. http://dx.doi.org/10.1016/j.evalprogplan.2005.07.003

Flint, D. J.; Blocker, C. P.; Boutin Jr., P. J. 2011. Customer value anticipation, customer satisfaction and loyalty: an empirical examination, Industrial Marketing Management 40(2): 219-230. http://dx.doi.org/10.1016/j.indmarman.2010.06.034

Fouladgar, M. M.; Yazdani-Chamzini, A.; Zavadskas, E. K.; Haji Moini, S. H. 2012. A new hybrid model for evaluating the working strategies: case study of construction company, Technological and Economic Development of Economy 18(1): 164-188. http://dx.doi.org/10.3846/20294913.2012.667270

Gaiardelli, P.; Saccani, N.; Songini, L. 2007. Performance measurement of the after-sales service networkevidence from the automotive industry, Computers in Industry 58(7): 698-708. http://dx.doi.org/10.1016/j.compind.2007.05.008

Garther. 2012. [online], [cited 6 November 2013]. Available from Internet: http://www.gartner.com/ technology/home.jsp

Gray, J. V.; Roth, A. V.; Leiblein, M. J. 2011. Quality risk in offshore manufacturing: evidence from the pharmaceutical industry, Journal of Operations Management 29(7-8): 737-752. http://dx.doi.org/10.1016/j.jom.2011.06.004

Gumus, A. T. 2009. Evaluation of hazardous waste transportation firms by using a two step fuzzy-AHP and TOPSIS methodology, Expert Systems with Applications 36(2): 4067-4074. http://dx.doi.org/10.1016/j.eswa.2008.03.013

Heo, E.; Kim, J.; Cho, S. 2012. Selecting hydrogen production methods using fuzzy analytic hierarchy process with opportunities, costs, and risks, International Journal of Hydrogen Energy 37(23): 17655-17662. http://dx.doi.org/10.1016/j.ijhydene.2012.09.055

Herrera, F.; Herrera-Viedma, E. 2000. Linguistic decision analysis: steps for solving decision problems under linguistic information, Fuzzy Sets and Systems 115(1): 67-82. http://dx.doi.org/10.1016/S0165-0114(99)00024-X

Hwang, C. L.; Yoon, K. 1981. Multiple attributes decision making methods and applications. Berlin: Springer. $259 \mathrm{p}$.

International Data Corporation (IDC). 2012. [online], [cited 6 November 2013]. Available from Internet: http://news.cnet.com/8301-1001_3-57453525-92/idc-forecast-ipad-up-android-down-blackberryirrelevant/

Jadhav, A. S.; Sonar, R. M. 2009. Evaluating and selecting software packages: a review, Information and Software Technology 51(3): 555-563. http://dx.doi.org/10.1016/j.infsof.2008.09.003

Jadhav, A. S.; Sonar, R. M. 2011. Framework for evaluation and selection of the software packages: a hybrid knowledge based system approach, Journal of Systems and Software 84(8): 1394-1407. http://dx.doi.org/10.1016/j.jss.2011.03.034

Jung, U.; Seo, D. W. 2010. An ANP approach for R\&D project evaluation based on interdependencies between research objectives and evaluation criteria, Decision Support Systems 49(3): 335-342. http://dx.doi.org/10.1016/j.dss.2010.04.005

Korhonen, P.; Voutilainen, R. 2006. Finding the most preferred alliance structure between banks and insurance companies, European Journal of Operational Research 175(2): 1285-1299. http://dx.doi.org/10.1016/j.ejor.2005.04.046

Kuo, M. S.; Liang, G. S. 2011. Combining VIKOR with GRA techniques to evaluate service quality of airports under fuzzy environment, Expert Systems with Applications 38(3): 1304-1312. http://dx.doi.org/10.1016/j.eswa.2010.07.003

Lee, A. H. I.; Chang, H. J.; Lin, C. Y. 2009. An evaluation model of buyer-supplier relationships in hightech industry - the case of an electronic components manufacturer in Taiwan, Computers \& Industrial Engineering 57(4): 1417-1430. http://dx.doi.org/10.1016/j.cie.2009.07.012 
Lee, A. H. I.; Chen, H. H.; Kang, H. Y. 2011b. A model to analyze strategic products for photovoltaic silicon thin-film solar cell power industry, Renewable and Sustainable Energy Reviews 15(2): 1271-1283. http://dx.doi.org/10.1016/j.rser.2010.10.008

Lee, H.; Kim, C.; Park, Y. 2010. Evaluation and management of new service concepts: An ANP-based portfolio approach, Computers \& Industrial Engineering 58(4): 535-543.

http://dx.doi.org/10.1016/j.cie.2009.11.016

Lee, J. W.; Kim, S. H. 2000. Using analytic network process and goal programming for interdependent information system project selection, Computers \& Operations Research 27(4): 367-382. http://dx.doi.org/10.1016/S0305-0548(99)00057-X

Lee, S. K.; Mogi, G.; Lee, S. K.; Kim, J. W. 2011a. Prioritizing the weights of hydrogen energy technologies in the sector of the hydrogen economy by using a fuzzy AHP approach, International Journal of Hydrogen Energy 36(2): 1897-1902. http://dx.doi.org/10.1016/j.ijhydene.2010.01.035

Lee, Y.; Kozar, K. A. 2006. Investigating the effect of website quality on e-business success: an analytic hierarchy process (AHP) approach, Decision Support Systems 42(3): 1383-1401. http://dx.doi.org/10.1016/j.dss.2005.11.005

Li, Y.; Liao, X. 2007. Decision support for risk analysis on dynamic alliance, Decision Support Systems 42(4): 2043-2059. http://dx.doi.org/10.1016/j.dss.2004.11.008

Liang, C.; Li, Q. 2008. Enterprise information system project selection with regard to BOCR, International Journal of Project Management 26(8): 810-820. http://dx.doi.org/10.1016/j.ijproman.2007.11.001

Lin, C. L.; Chen, C. W.; Tzeng, G. H. 2010. Planning the development strategy for the mobile communication package based on consumers' choice preferences, Expert Systems with Application 37(7): 4749-4760. http://dx.doi.org/10.1016/j.eswa.2009.11.009

Lin, H. Y.; Hsu, P. Y.; Sheen, G. J. 2007. A fuzzy-based decision-making procedure for data warehouse system selection, Expert Systems with Applications 32(3): 939-953.

http://dx.doi.org/10.1016/j.eswa.2006.01.031

Liou, J. J. H.; Tzeng, G. H.; Tsai, C. Y.; Hsu, C. C. 2011. A hybrid ANP model in fuzzy environments for strategic alliance partner selection in the airline industry, Applied Soft Computing 11(4): 3515-3524. http://dx.doi.org/10.1016/j.asoc.2011.01.024

Liu, J. W.; Cheng, C. H.; Chen, Y. H.; Chen, T. L. 2010. OWA rough set model for forecasting the revenues growth rate of the electronic industry, Expert Systems with Applications 37(1): 610-617. http://dx.doi.org/10.1016/j.eswa.2009.06.020

Markarian, G.; Pozza, L.; Prencipe, A. 2008. Capitalization of R\&D costs and earnings management: evidence from Italian listed companies, The International Journal of Accounting 43(3): 246-267. http:// dx.doi.org/10.1016/j.intacc.2008.06.002

Mikhailov, L. 2004. A fuzzy approach to deriving priorities from interval pairwise comparison judgments, European Journal of Operational Research 159(3): 687-704.

http://dx.doi.org/10.1016/S0377-2217(03)00432-6

Moon, J.; Chadee, D.; Tikoo, S. 2008. Culture, product type, and price influences on consumer purchase intention to buy personalized products online, Journal of Business Research 61(1): 31-39. http://dx.doi.org/10.1016/j.jbusres.2006.05.012

Opricovic, S. 1998. Multi-criteria optimization of civil engineering systems. Faculty of Civil Engineering, Belgrade.

Opricovic, S.; Tzeng, G. H. 2004. Compromise solution by MCDM methods: a comparative analysis of VIKOR and TOPSIS, European Journal of Operational Research 156(2): 445-455. http://dx.doi.org/10.1016/S0377-2217(03)00020-1

Porter, M. E. 1980. Competitive strategy: techniques for analyzing industries and competitors. New York: The Free Press. 432 p. 
Ramanathan, R. 2010. The moderating roles of risk and efficiency on the relationship between logistics performance and customer loyalty in e-commerce, Transportation Research Part E 46(6): 950-962. http://dx.doi.org/10.1016/j.tre.2010.02.002

Saaty, T. L. 1996. Decision making with dependence and feedback: the analytic network process. RWS Publications: Pittsburgh. 370 p.

Saaty, T. L.; Ozdemir, M. 2003. Negative priorities in the analytic hierarchy process, Mathematical and Computer Modelling 37(9-10): 1063-1075. http://dx.doi.org/10.1016/S0895-7177(03)00118-3

Saaty, T. L. 1980. The analytic hierarchy process. New York: McGraw-Hill. 287 p.

Secme, N. Y.; Bayrakdaroglu, A.; Kahraman, C. 2009. Fuzzy performance evaluation in Turkish banking sector using analytic hierarchy process and TOPSIS, Expert Systems with Application 36(9): 1169911709. http://dx.doi.org/10.1016/j.eswa.2009.03.013

Sevkli, M.; Oztekin, A.; Uysal, O.; Torlak, G.; Turkyilmaz, A.; Delen, D. 2012. Development of a fuzzy ANP based SWOT analysis for the airline industry in Turkey, Expert Systems with Applications 39(1): 14-24. http://dx.doi.org/10.1016/j.eswa.2011.06.047

Tsai, C. C. 2012. A research on selecting criteria for new green product development project: taking Taiwan consumer electronics products as an example, Journal of Cleaner Production 25: 106-115. http://dx.doi.org/10.1016/j.jclepro.2011.12.002

Tzeng, G. H.; Teng, M. H.; Chen, J. J.; Opricovic, S. 2002. Multicriteria selection for a restaurant location in Taipei, International Journal of Hospitality Management 21(2): 171-187. http://dx.doi.org/10.1016/S0278-4319(02)00005-1

Wang, C. H.; Lu, I. Y.; Chen, C. B. 2010. Integrating hierarchical balanced scorecard with non-additive fuzzy integral for evaluating high technology firm performance, International Journal of Production Economics 128(1): 413-426. http://dx.doi.org/10.1016/j.ijpe.2010.07.042

Wijnmalen, D. J. D. 2007. Analysis of benefits, opportunities, costs, and risks (BOCR) with the AHP-ANP: a critical validation, Mathematical and Computer Modelling 46(7-8): 892-905. http://dx.doi.org/10.1016/j.mcm.2007.03.020

Wu, C. R.; Lin, C. T.; Tsai, P. H. 2009b. Analysing alternatives in financial services for wealth management banks: the analytic network process and the balanced scorecard approach, IMA Journal of Management Mathematics 20(3): 303-321. http://dx.doi.org/10.1093/imaman/dpp002

Wu, C. R.; Lin, C. T.; Tsai, P. H. 2010. Evaluating business performance of wealth management banks, European Journal of Operational Research 207(2): 971-979. http://dx.doi.org/10.1016/j.ejor.2010.04.034

Wu, C. R.; Lin, C. T.; Tsai, P. H. 2011a. Financial service sector performance measurement model: AHP sensitivity analysis and balanced scorecard approach, The Service Industries Journal 31(5): 695-711. http://dx.doi.org/10.1080/02642060902852908

Wu, H. Y.; Lin, Y. K.; Chang, C. H. 2011b. Performance evaluation of extension education centers in universities based on the balanced scorecard, Evaluation and Program Planning 34(1): 37-50. http://dx.doi.org.10.1016/j.evalprogplan.2010.06.001

Wu, H. Y.; Tzeng, G. H.; Chen, Y. H. 2009a. A fuzzy MCDM approach for evaluating banking performance based on Balanced Scorecard, Expert Systems with Applications 36(6): 10135-10147. http://dx.doi.org/10.1016/j.eswa.2009.01.005

Yurdakul, M.; Tansel İç, Y. 2004. AHP approach in the credit evaluation of the manufacturing firms in Turkey, International Journal of Production Economics 88(3): 269-289. http://dx.doi.org/10.1016/S0925-5273(03)00189-0

Zavadskas, E. K.; Turskis, Z. 2011. Multiple criteria decision making (MCDM) methods in economics: an overview, Technological and Economic Development of Economy 17(2): 397-427. http://dx.doi.org/10.3846/20294913.20n.593291

Zhang, Y. J.; Fan, J. L.; Chang, H. R. 2011. Impact of China's stock market development on energy consumption: an empirical analysis, Energy Procedia 5: 1927-1931.

Zimmermann, H. J. 1991. Fuzzy Set Theory and its applications. Boston: Kluwer Academic. 399 p. 


\section{APPENDIX}

Table A1. Supporting literature of the BOCR performance evaluation criteria and sub-criteria

\begin{tabular}{|c|c|c|c|}
\hline $\begin{array}{c}\text { Crite- } \\
\text { ria }\end{array}$ & $\begin{array}{c}\text { Supporting } \\
\text { literature }\end{array}$ & Sub-criteria & Supporting literature \\
\hline \multirow{5}{*}{$\begin{array}{l}\text { Benefits } \\
\text { (B) }\end{array}$} & \multirow{5}{*}{$\begin{array}{l}\text { Saaty (1996); } \\
\text { Saaty and } \\
\text { Ozdemir } \\
\text { (2003); } \\
\text { Wijnmalen } \\
(2007)\end{array}$} & Revenue growth $\left(\mathrm{B}_{1}\right)$ & Cebeci (2009); Liu et al. (2010) \\
\hline & & Sales and marketing $\left(\mathrm{B}_{2}\right)$ & $\begin{array}{l}\text { Cook and Hababou (2001); } \\
\text { Amiri et al. (2009) }\end{array}$ \\
\hline & & $\begin{array}{l}\text { Capacity for profitability } \\
\left(\mathrm{B}_{3}\right)\end{array}$ & $\begin{array}{l}\text { Cebeci (2009); Wu et al. (2010); } \\
\text { Lee et al. (2010) }\end{array}$ \\
\hline & & Product price $\left(\mathrm{B}_{4}\right)$ & $\begin{array}{l}\text { Chan and Kumar (2007); Moon et al. (2008); } \\
\text { Lin et al. (2010) }\end{array}$ \\
\hline & & Customer loyalty $\left(\mathrm{B}_{5}\right)$ & $\begin{array}{l}\text { Flint et al. (2011); Ramanathan (2010); } \\
\text { Deng et al. (2010) }\end{array}$ \\
\hline \multirow{7}{*}{$\begin{array}{l}\text { Oppor- } \\
\text { tunity } \\
\text { (O) }\end{array}$} & \multirow{7}{*}{$\begin{array}{l}\text { Saaty (1996); } \\
\text { Saaty and } \\
\text { Ozdemir } \\
\text { (2003); } \\
\text { Wijnmalen } \\
(2007)\end{array}$} & Product design $\left(\mathrm{O}_{1}\right)$ & Chan et al. (2010); Lin et al. (2010) \\
\hline & & Product function $\left(\mathrm{O}_{2}\right)$ & Lin et al. (2010) \\
\hline & & $\begin{array}{l}\text { Product derived function } \\
\left(\mathrm{O}_{3}\right)\end{array}$ & Lin et al. (2010) \\
\hline & & After-sales service $\left(\mathrm{O}_{4}\right)$ & Birgelen et al. (2002); Gaiardelli et al. (2007) \\
\hline & & System choice $\left(\mathrm{O}_{5}\right)$ & Lin et al. (2007); Jadhav and Sonar (2011) \\
\hline & & $\begin{array}{l}\text { Learning and innovation } \\
\left(\mathrm{O}_{6}\right)\end{array}$ & Lee and Kim (2000); Chen et al. (2010b). \\
\hline & & Strategic alliance $\left(\mathrm{O}_{7}\right)$ & $\begin{array}{l}\text { Korhonen and Voutilainen (2006); Chen } \\
\text { et al. (2010b); Liou et al. (2011) }\end{array}$ \\
\hline \multirow{5}{*}{$\begin{array}{l}\text { Costs } \\
\text { (C) }\end{array}$} & \multirow{5}{*}{$\begin{array}{l}\text { Saaty (1996); } \\
\text { Saaty and } \\
\text { Ozdemir } \\
(2003) ; \\
\text { Wijnmalen } \\
(2007)\end{array}$} & Implementation cost $\left(\mathrm{C}_{1}\right)$ & Liang and Li (2008); Lee et al. (2010) \\
\hline & & Product cost $\left(\mathrm{C}_{2}\right)$ & Chan and Kumar (2007); Lee et al. (2011b) \\
\hline & & $R \& D$ cost $\left(C_{3}\right)$ & Markarian et al. (2008); Wang et al. (2010) \\
\hline & & Maintenance cost $\left(\mathrm{C}_{4}\right)$ & $\begin{array}{l}\text { Lee and Kim (2000); Liang and Li (2008); } \\
\text { Jadhav and Sonar (2009) }\end{array}$ \\
\hline & & System quality $\left(\mathrm{C}_{5}\right)$ & Lee and Kozar (2006) \\
\hline \multirow{5}{*}{$\begin{array}{l}\text { Risks } \\
\text { (R) }\end{array}$} & \multirow{5}{*}{$\begin{array}{l}\text { Saaty (1996); } \\
\text { Saaty and } \\
\text { Ozdemir } \\
\text { (2003); } \\
\text { Wijnmalen } \\
(2007)\end{array}$} & $\begin{array}{l}\text { Potential competitor } \\
\text { threats }\left(\mathrm{R}_{1}\right)\end{array}$ & Porter (1980) \\
\hline & & Financial risks $\left(\mathrm{R}_{2}\right)$ & Yurdakul and Tansel İç (2004) \\
\hline & & Market risks $\left(\mathrm{R}_{3}\right)$ & Li and Liao (2007) \\
\hline & & Quality risks $\left(\mathrm{RC}_{4}\right)$ & Li and Liao (2007); Gray et al. (2011) \\
\hline & & $\begin{array}{l}\text { Technical innovation } \\
\text { risks }\left(C_{5}\right)\end{array}$ & Li and Liao (2007) \\
\hline
\end{tabular}


Table A2. Brief description of seven alternatives among tablet PCs

\begin{tabular}{|c|c|}
\hline Tablet PCs & Description \\
\hline Apple iPad & $\begin{array}{l}\text { The iPad is the first tablet computer from Apple (2010). The iPad is designed for } \\
\text { consumers who want a mobile device that is bigger than a smartphone but smaller } \\
\text { than a laptop for entertainment multimedia. }\end{array}$ \\
\hline HP TouchPad & $\begin{array}{l}\text { The HP TouchPad is a tablet computer developed and designed by Hewlett-Packard } \\
\text { (HP). The HP TouchPad was launched on July } 1,2011 \text { in the U.S. The HP TouchPad } \\
\text { is one of many new multi-touch, capacitive touchscreen tablets, such as the Apple } \\
\text { iPad and Android tablets, but the TouchPad runs HP webOS, which has several no- } \\
\text { table features, sharing the same card multitasking found in the Palm Pre 2, HP Veer, } \\
\text { and HP Pre } 3 \text { including the highly regarded "stack" feature. }\end{array}$ \\
\hline $\begin{array}{l}\text { Motorola } \\
\text { Xoom }\end{array}$ & $\begin{array}{l}\text { The Motorola Xoom was introduced at CES } 2011 \text { on January 5, 2011. It is the first } \\
\text { tablet to touchdown with Android 3.0, Honeycomb, and the Google operating sys- } \\
\text { tem designed for tablet devices. }\end{array}$ \\
\hline $\begin{array}{l}\text { BlackBerry } \\
\text { PlayBook }\end{array}$ & $\begin{array}{l}\text { The BlackBerry PlayBook is a tablet computer by Research in Motion (RIM). The } \\
\text { BlackBerry PlayBook (launched April 2011) has multi-touch capacitive 7-inch dis- } \\
\text { play, 1GHz dual-core CPU, 1GB of RAM, an e-reader app, and the ability to tether } \\
\text { to a BlackBerry phone. }\end{array}$ \\
\hline $\begin{array}{l}\text { Samsung Gal- } \\
\text { axy Tab }\end{array}$ & $\begin{array}{l}\text { The Samsung Galaxy Tab is an Android-based tablet computer produced by Sam- } \\
\text { sung that debuted on September at the } 2010 \text { IFA in Berlin. The Galaxy Tab features } \\
\text { a } 7 \text {-inch }(180 \mathrm{~mm}) \text { TFT-LCD touchscreen, Wi-Fi capability, a } 1.0 \mathrm{GHz} \text { ARM Cor- } \\
\text { tex-A8 processor, the Swype input system, a } 3.2 \text { MP rear-facing camera and a } 1.3 \\
\text { MP front-facing camera for video calls running the Android } 2.2 \text { operating system. }\end{array}$ \\
\hline $\begin{array}{l}\text { Asus Eee Pad } \\
\text { Transformer }\end{array}$ & $\begin{array}{l}\text { The Asus Eee Pad Transformer is an Android 3.2 Honeycomb tablet computer an- } \\
\text { nounced at CES } 2011 \text { and launched on March 30, 2011. The Transformer design } \\
\text { includes an optional docking keyboard. }\end{array}$ \\
\hline $\begin{array}{l}\text { Acer Iconia } \\
\text { Tab W500 }\end{array}$ & $\begin{array}{l}\text { Acer's new Iconia Tab W500 lightweight tablet computer features a 10.1-inch } \\
\text { screen, 1080p video support, and a full-size docking chiclet keyboard. }\end{array}$ \\
\hline
\end{tabular}

Table A3. Criteria for aggregate pairwise comparison matrix for sub-criteria of level 3

\begin{tabular}{cccccccc}
\hline $\begin{array}{c}\text { Benefits } \\
(\mathrm{B})\end{array}$ & $\mathrm{B}_{1}$ & $\mathrm{~B}_{2}$ & $\mathrm{~B}_{3}$ & $\mathrm{~B}_{4}$ & $\mathrm{~B}_{5}$ & $\mathrm{~B}_{6}$ & \\
\hline $\mathrm{B}_{1}$ & 1.000 & 1.946 & 1.280 & 1.477 & 1.161 & 1.054 & \\
$\mathrm{~B}_{2}$ & 0.514 & 1.000 & 1.285 & 1.395 & 1.186 & 0.984 & \\
$\mathrm{~B}_{3}$ & 0.781 & 0.778 & 1.000 & 1.514 & 1.835 & 1.614 & \\
$\mathrm{~B}_{4}$ & 0.677 & 0.717 & 0.660 & 1.000 & 1.713 & 1.544 & \\
$\mathrm{~B}_{5}$ & 0.862 & 0.843 & 0.545 & 0.584 & 1.000 & 0.891 & \\
$\mathrm{~B}_{6}$ & 0.948 & 1.016 & 0.619 & 0.647 & 1.122 & 1.000 & \\
\hline Opportu- $_{\text {nity }(\mathrm{O})}$ & $\mathrm{O}_{1}$ & $\mathrm{O}_{2}$ & $\mathrm{O}_{3}$ & $\mathrm{O}_{4}$ & $\mathrm{O}_{5}$ & $\mathrm{O}_{6}$ & $\mathrm{O}_{7}$ \\
\hline $\mathrm{O}_{1}$ & 1.000 & 2.144 & 1.876 & 1.400 & 1.384 & 1.629 & 1.471 \\
$\mathrm{O}_{2}$ & 0.466 & 1.000 & 1.110 & 1.687 & 1.313 & 1.230 & 1.131 \\
$\mathrm{O}_{3}$ & 0.533 & 0.901 & 1.000 & 1.219 & 0.708 & 1.062 & 0.848 \\
$\mathrm{O}_{4}$ & 0.714 & 0.593 & 0.821 & 1.000 & 0.772 & 0.797 & 0.859
\end{tabular}


Continued Table A3

\begin{tabular}{cccccccc}
\hline $\begin{array}{c}\text { Benefits } \\
(\mathrm{B})\end{array}$ & $\mathrm{B}_{1}$ & $\mathrm{~B}_{2}$ & $\mathrm{~B}_{3}$ & $\mathrm{~B}_{4}$ & $\mathrm{~B}_{5}$ & $\mathrm{~B}_{6}$ & \\
\hline $\mathrm{O}_{5}$ & 0.723 & 0.762 & 1.412 & 1.295 & 1.000 & 1.209 & 1.213 \\
$\mathrm{O}_{6}$ & 0.614 & 0.813 & 0.942 & 1.255 & 0.827 & 1.000 & 0.910 \\
$\mathrm{O}_{7}$ & 0.850 & 0.884 & 1.180 & 1.165 & 0.824 & 1.098 & 1.000 \\
\hline Costs $(\mathrm{C})$ & $\mathrm{C}_{1}$ & $\mathrm{C}_{2}$ & $\mathrm{C}_{3}$ & $\mathrm{C}_{4}$ & $\mathrm{C}_{5}$ & & \\
\hline $\mathrm{C}_{1}$ & 1.000 & 1.252 & 1.243 & 1.361 & 1.293 & & \\
$\mathrm{C}_{2}$ & 0.799 & 1.000 & 1.129 & 1.505 & 1.677 & & \\
$\mathrm{C}_{3}$ & 0.804 & 0.885 & 1.000 & 1.643 & 1.310 & & \\
$\mathrm{C}_{4}$ & 0.735 & 0.665 & 0.609 & 1.000 & 1.255 & & \\
$\mathrm{C}_{5}$ & 0.773 & 0.596 & 0.763 & 0.797 & 1.000 & & \\
\hline Risks $(\mathrm{R})$ & $\mathrm{R}_{1}$ & $\mathrm{R}_{2}$ & $\mathrm{R}_{3}$ & $\mathrm{R}_{4}$ & $\mathrm{R}_{5}$ & & \\
\hline $\mathrm{R}_{1}$ & 1.000 & 1.812 & 2.389 & 1.746 & 1.811 & & \\
$\mathrm{R}_{2}$ & 0.552 & 1.000 & 1.049 & 1.455 & 1.214 & & \\
$\mathrm{R}_{3}$ & 0.419 & 0.953 & 1.000 & 1.468 & 1.030 & & \\
$\mathrm{R}_{4}$ & 0.573 & 0.687 & 0.681 & 1.000 & 0.955 & & \\
$\mathrm{R}_{5}$ & 0.552 & 0.824 & 0.971 & 1.047 & 1.000 & & \\
\hline
\end{tabular}

Note: Benefits (B): $\lambda_{\text {max }}=6.150 ; \mathrm{CI}=0.030 ; \mathrm{RI}=1.240 ; \mathrm{CR}=0.024 \leq 0.1 ;$ Opportunity $(\mathrm{O}): \lambda_{\max }=7.060 ; \mathrm{CI}=$ $0.010 ; \mathrm{RI}=1.300 ; \mathrm{CR}=0.008 \leq 0.1$; Costs $(\mathrm{C}): \lambda_{\max }=5.040 ; \mathrm{CI}=0.010 ; \mathrm{RI}=1.100 ; \mathrm{CR}=0.009 \leq 0.1$; Risks $(\mathrm{R}): \lambda_{\text {max }}=5.040 ; \mathrm{CI}=0.010 ; \mathrm{RI}=1.100 ; \mathrm{CR}=0.009 \leq 0.1$.

Table A4. Performance matrix with the best value and the worst value by VIKOR

\begin{tabular}{cccccccccc}
\hline Indexes & Apple & $\mathrm{HP}$ & $\begin{array}{c}\text { Mo- } \\
\text { torola }\end{array}$ & $\mathrm{BB}$ & $\begin{array}{c}\text { Sam- } \\
\text { sung }\end{array}$ & Asus & Acer & $f_{j}^{*}$ & $f_{j}^{-}$ \\
\hline $\mathrm{B}_{1}{ }^{\mathrm{a}}$ & 0.433 & 0.098 & 0.092 & 0.079 & 0.104 & 0.110 & 0.084 & 0.433 & 0.079 \\
$\mathrm{~B}_{2}{ }^{\mathrm{a}}$ & 0.449 & 0.100 & 0.093 & 0.072 & 0.108 & 0.098 & 0.079 & 0.449 & 0.072 \\
$\mathrm{~B}_{3}{ }^{\mathrm{a}}$ & 0.468 & 0.102 & 0.087 & 0.073 & 0.102 & 0.088 & 0.081 & 0.468 & 0.073 \\
$\mathrm{~B}_{4}{ }^{\mathrm{a}}$ & 0.370 & 0.103 & 0.101 & 0.090 & 0.127 & 0.117 & 0.092 & 0.370 & 0.090 \\
$\mathrm{~B}_{5}{ }^{\mathrm{a}}$ & 0.483 & 0.091 & 0.094 & 0.088 & 0.094 & 0.082 & 0.069 & 0.483 & 0.069 \\
$\mathrm{~B}_{6}{ }^{\mathrm{a}}$ & 0.493 & 0.083 & 0.091 & 0.087 & 0.094 & 0.076 & 0.076 & 0.493 & 0.076 \\
$\mathrm{O}_{1}{ }^{\mathrm{a}}$ & 0.477 & 0.092 & 0.096 & 0.082 & 0.091 & 0.090 & 0.071 & 0.477 & 0.071 \\
$\mathrm{O}_{2}{ }^{\mathrm{a}}$ & 0.408 & 0.098 & 0.091 & 0.095 & 0.108 & 0.113 & 0.088 & 0.408 & 0.088 \\
$\mathrm{O}_{3}{ }^{\mathrm{a}}$ & 0.409 & 0.106 & 0.099 & 0.100 & 0.095 & 0.104 & 0.088 & 0.409 & 0.088 \\
$\mathrm{O}_{4}{ }^{a}$ & 0.341 & 0.113 & 0.109 & 0.090 & 0.113 & 0.116 & 0.117 & 0.341 & 0.090 \\
$\mathrm{O}_{5}{ }^{a}$ & 0.382 & 0.106 & 0.103 & 0.105 & 0.105 & 0.099 & 0.100 & 0.382 & 0.099 \\
$\mathrm{O}_{6}{ }^{a}$ & 0.454 & 0.088 & 0.089 & 0.080 & 0.102 & 0.111 & 0.076 & 0.454 & 0.076 \\
$\mathrm{O}_{7}{ }^{a}$ & 0.339 & 0.120 & 0.115 & 0.101 & 0.112 & 0.114 & 0.098 & 0.339 & 0.098
\end{tabular}


Continued Table A4

\begin{tabular}{cccccccccc}
\hline Indexes & Apple & HP & $\begin{array}{c}\text { Mo- } \\
\text { torola }\end{array}$ & BB & $\begin{array}{c}\text { Sam- } \\
\text { sung }\end{array}$ & Asus & Acer & $f_{j}^{*}$ & $f_{j}^{-}$ \\
\hline $\mathrm{C}_{1}{ }^{\mathrm{b}}$ & 0.409 & 0.105 & 0.087 & 0.090 & 0.116 & 0.101 & 0.093 & 0.087 & 0.409 \\
$\mathrm{C}_{2}{ }^{\mathrm{b}}$ & 0.423 & 0.111 & 0.083 & 0.078 & 0.107 & 0.103 & 0.094 & 0.078 & 0.423 \\
$\mathrm{C}_{3}{ }^{\mathrm{b}}$ & 0.436 & 0.098 & 0.104 & 0.101 & 0.103 & 0.084 & 0.075 & 0.075 & 0.436 \\
$\mathrm{C}_{4}{ }^{\mathrm{b}}$ & 0.437 & 0.099 & 0.079 & 0.091 & 0.100 & 0.100 & 0.095 & 0.079 & 0.437 \\
$\mathrm{C}_{5}{ }^{\mathrm{b}}$ & 0.425 & 0.103 & 0.092 & 0.088 & 0.099 & 0.100 & 0.093 & 0.088 & 0.425 \\
$\mathrm{R}_{1}{ }^{\mathrm{b}}$ & 0.321 & 0.106 & 0.121 & 0.109 & 0.118 & 0.121 & 0.104 & 0.104 & 0.321 \\
$\mathrm{R}_{2}{ }^{\mathrm{b}}$ & 0.299 & 0.130 & 0.125 & 0.112 & 0.120 & 0.112 & 0.101 & 0.101 & 0.299 \\
$\mathrm{R}_{3}{ }^{\mathrm{b}}$ & 0.237 & 0.133 & 0.128 & 0.134 & 0.129 & 0.122 & 0.116 & 0.116 & 0.237 \\
$\mathrm{R}_{4}{ }^{\mathrm{b}}$ & 0.255 & 0.116 & 0.109 & 0.118 & 0.139 & 0.134 & 0.128 & 0.109 & 0.255 \\
$\mathrm{R}_{5}{ }^{\mathrm{b}}$ & 0.292 & 0.117 & 0.118 & 0.116 & 0.130 & 0.121 & 0.106 & 0.106 & 0.292 \\
\hline
\end{tabular}

Note: a: Indicates that the evaluation indicator is associated with benefits and opportunity criteria and the maximum is the ideal solution; b: Indicates that the evaluation indicator is associated with cost and risk criteria and the minimum is the ideal solution.

Table A5. The values $S_{i}$ and $R_{i}$ by VIKOR

\begin{tabular}{ccc}
\hline Tablet PCs selection & $S_{i}$ & $R_{i}$ \\
\hline Apple $\left(\mathrm{Al}_{1}\right)$ & $0.000(1)$ & $0.000(1)$ \\
HP $\left(\mathrm{Al}_{2}\right)$ & $3.754(4)$ & $0.321(6)$ \\
Motorola $\left(\mathrm{Al}_{3}\right)$ & $3.815(5)$ & $0.298(2)$ \\
BB $\left(\mathrm{Al}_{4}\right)$ & $3.887(6)$ & $0.317(5)$ \\
Samsung $\left(\mathrm{Al}_{5}\right)$ & $3.689(2)$ & $0.303(4)$ \\
Asus $\left(\mathrm{Al}_{6}\right)$ & $3.753(3)$ & $0.299(3)$ \\
Acer $\left(\mathrm{Al}_{7}\right)$ & $3.932(7)$ & $0.325(7)$ \\
\hline
\end{tabular}

Note: () denotes ranking order.

Table A6. Fuzzy pairwise comparison matrix of four decision criteria with respect to the goal

\begin{tabular}{cccccc}
\hline Criteria & $\mathrm{B}$ & $\mathrm{O}$ & $\mathrm{C}$ & $\mathrm{R}$ & Weights \\
\hline \multirow{2}{*}{$\mathrm{B}$} & $(1,1,1)$ & $(1.676,2.097$, & $(1.316,1.698$, & $(1.228,1.561$, & \multirow{2}{*}{0.479} \\
& $2.557)$ & $2.069)$ & $1.957)$ & \\
$\mathrm{O}$ & $(0.391,0.477$, & $(1,1,1)$ & $(1.328,1.820$, & $(1.278,1.662$, & 0.324 \\
& $0.597)$ & & $2.324)$ & $2.086)$ & \\
$\mathrm{C}$ & $(0.483,0.589$, & $(0.430,0.550$, & $(1,1,1)$ & $(1.273,1.689$, & 0.161 \\
& $0.760)$ & $0.753)$ & $2.134)$ & \\
$\mathrm{R}$ & $(0.511,0.641$, & $(0.479,0.602$, & $(0.469,0.592$, & $(1,1,1)$ & 0.036 \\
\hline
\end{tabular}

Note: $\mathrm{B}=$ Benefits, $\mathrm{O}=$ Opportunity, $\mathrm{C}=$ Costs, and $\mathrm{R}=$ Risks. 
Table A7. The importance weights of sub-criteria with BOCR by FAHP

\begin{tabular}{cccccccc}
\hline Benefits & Weights & $\begin{array}{c}\text { Opportu- } \\
\text { nity }\end{array}$ & Weights & Costs & Weights & Risks & Weights \\
\hline $\mathrm{B}_{1}$ & 0.230 & $\mathrm{O}_{1}$ & 0.248 & $\mathrm{C}_{1}$ & 0.252 & $\mathrm{R}_{1}$ & 0.466 \\
$\mathrm{~B}_{2}$ & 0.171 & $\mathrm{O}_{2}$ & 0.171 & $\mathrm{C}_{2}$ & 0.250 & $\mathrm{R}_{2}$ & 0.218 \\
$\mathrm{~B}_{3}$ & 0.217 & $\mathrm{O}_{3}$ & 0.098 & $\mathrm{C}_{3}$ & 0.227 & $\mathrm{R}_{3}$ & 0.160 \\
$\mathrm{~B}_{4}$ & 0.169 & $\mathrm{O}_{4}$ & 0.070 & $\mathrm{C}_{4}$ & 0.149 & $\mathrm{R}_{4}$ & 0.058 \\
$\mathrm{~B}_{5}$ & 0.087 & $\mathrm{O}_{5}$ & 0.159 & $\mathrm{C}_{5}$ & 0.122 & $\mathrm{R}_{5}$ & 0.098 \\
$\mathrm{~B}_{6}$ & 0.126 & $\mathrm{O}_{6}$ & 0.114 & & & & \\
& & $\mathrm{O}_{7}$ & 0.140 & & & & \\
\hline
\end{tabular}

Peihsuan TSAI is a Doctoral Candidate in Department of Business Administration at National Taiwan University of Science and Technology (NTUST). He received the BE and MA degree in Finance and Business Management from Yuanpei University, repectively. He has published 5 papers in international journals including journals such as Technological and Economic Development of Economy, IMA Journal of Management Mathematics, European Journal of Operational Research, Service Industries Journal, Journal of Social Sciences, and Journal of Information and Optimization Sciences. His main research interests include multi-criteria decision-making (MCDM), performance management, and management sciences.

Shunchiao CHANG has a MA and a PhD degree in Economics from National Tsing Hua University and SUNY at Stony Brook (US), respectively. He is a Professor in the Department of Business Administration and a Director of Leader Project at National Taiwan University of Science and Technology (NTUST). He has published more than 12 papers in journals, books, and conference proceedings including journals such as Journal of Economic Dynamics and Control, Global Economic Review, Tourism Economics, Economic Modelling, and Technological and Economic Development of Economy. His main research interests include the economic and strategic analysis of high-tech industry and global service trade. 